\title{
Associations between forest vegetation and the fertility of soil organic horizons in northwestern Russia
}

\author{
Natalia V. Lukina ${ }^{1 *} \mathbb{D}$, Elena V. Tikhonova ${ }^{1}$, Maria A. Danilova', Olga N. Bakhmet², Aleksandr M. Kryshen², \\ Daria N. Tebenkova', Anastasia I. Kuznetsova', Vadim E. Smirnov' ${ }^{1}$, Tatiana Yu Braslavskaya ${ }^{1}$, Aleksey V. Gornov', \\ Maksim P. Shashkov', Svetlana V. Knyazeva ${ }^{3}$, Anton D. Kataev' ${ }^{1}$, Ludmila G. Isaeva ${ }^{4}$ and Natalia V. Zukert ${ }^{1}$
}

\begin{abstract}
Background: Being the product of the same environment, soil and vegetation are mutually associated with each other, but the relationships between edaphic properties and vegetation characteristics are still far from clear. Accordingly, the specific aim of this study is to identify relationships between forest site types/forest types and the fertility of soil organic horizons in northwestern Russia. The relationships were assessed at the level of three large forest regions, the northern and middle taiga of the Republic of Karelia, and the Karelian Isthmus (Leningrad region), based on 37 spruce, 66 pine, and 16 birch plots which were integrated with the International Cooperative Programme on Assessment and Monitoring of Air Pollution Effects on Forests (ICP Forests).

Results: Soil forming rock and land-use history partly explain the differences in the fertility of soil organic horizons between the forest ecosystems in northwestern Russia. Climatic factors are closely correlated with plant species richness, density and the fertility of soil organic horizons. Nutrient content in the organic horizons increased from poor to rich site types identified according to composition of understory vegetation and the occurrence of certain indicator species, i.e. Cajander's forest site types. The most informative parameters in explaining differences between Cajander's types were nitrogen, carbon to nitrogen ratio, exchangeable calcium, magnesium, potassium, and base saturation. Extractable phosphorus, carbon to nitrogen ratio, exchangeable calcium, magnesium, aluminum and base saturation were the most informative parameters in explaining differences between forest types identified within the Cajander types in accordance with the tree species composition, i.e. Sukachev's forest types. The organic horizons of spruce and birch-dominated forests contained significantly more nutrients, compared to those dominated by pine. These differences were explained by differences in litter quality, and the crown shape and density of tree species, which affect the intensity of nutrient leaching.

Conclusions: The study presents new findings regarding the relationships between forest sites/types and the fertility of soil organic horizons in northwestern Russia. Differences in organic horizon's fertility between the taiga subzones are explained by differences in the soil forming rock, climatic conditions, land-use history and shares of forest site types/forest types.
\end{abstract}

Keywords: Taiga forest, Cajander's forest site types, Sukachev's forest types, Soil fertility

\footnotetext{
* Correspondence: nvl07@yandex.ru

${ }^{1}$ Center for Forest Ecology and Productivity of the Russian Academy of

Sciences, 117997 Profsoyuznaya st. 84/32, RU-117997, Moscow, Russia

Full list of author information is available at the end of the article
} 


\section{Background}

Being the product of the same environment, soil and vegetation are mutually associated with each other, but the relationships between edaphic properties and vegetation characteristics are still far from clear. Vascular plants depend on soils for their nutrient and water supply, but soil is also considered to be a part of the extended phenotype of a plant (Jones et al. 1994; van Breemen and Finzi 1998). Plants influence mineral weathering and soil structure, while certain functional properties of plants influence the chemical and physical composition of litter, and thereby their decomposability. Trees affect the spatial redistribution of precipitation, and the fluxes of carbon and nutrients within forest ecosystems and landscapes (Karpachevsky 1978; Hobbie 1992; Lovett 1992; Binkley and Giardina 1998; Berg 2000; Cornelissen et al. 2007).

Non-vascular cryptogams, such as bryophytes and lichens which are widely distributed in boreal forests, are important hosts for nitrogen-fixing bacteria. Therefore, they act as a major nitrogen supply in soils and significantly contribute to aboveground biomass; they also control soil chemistry and nutrition through the accumulation of recalcitrant polyphenols (Cornelissen et al. 2007). New findings emerged during the 1990's regarding the impact of different trees species on the properties of forest soils (Binkley et al. 1992; Berkvist and Folkeson 1995). Augusto (2002) ranked the following tree species by their ability to reduce soil acidity: (Picea abies (L.) H. Karst., Picea sitchensis (Bong.) Carrière, Pinus sylvestris L.) > (Abies alba Mill., Pseudotsuga menziesii (Mirb.) Franco) > (Betula pendula Roth, Fagus sylvatica L., Quercus petraea (Matt.) Liebl., Quercus robur L.) $>$ (Acer platanoides L., Carpinus betulus L., Fraxinus excelsior L., Tilia cordata Mill.).

Orlova et al. (2016) found that the influence of Norway spruce ( $P$. abies) on the acidity of the organic horizon in northern taiga forest soils depends on the age of spruce trees. Young trees (30-50 years) contributed to increasing acidity of the organic horizon in the oldgrowth forests, compared to initial stages of forest soil development, but this was not the case for the old trees (> 100 years).

Experimental testing of the relationships between forest soil and vegetation, which is a basis for forest type classifications, is needed. According to the Finnish forest site classification (Cajander 1909, 1926, 1949) as well as Central-European Ellenberg system (Ellenberg et al. 1991), the composition of the understory vegetation reflects the fertility and productivity status of the site. Cajander's forest site type classification is in accordance with assumption that site productivity can be predicted on the basis of the occurrence of understory plants, which has been supported by experimental findings
(Salemaa et al. 2008). Sukachev (1972) has developed forest type classification taking into account the understory vegetation and tree species composition. Just like Cajander's classification in Finland, Sukachev's forest type classification is a well-established forestry tool in Russia (Alexandrova 1969; Frey 1978).

The aim of this study was to assess the fertility of soil organic horizons in the predominant forest types, and to identify relationships between the forest types and the fertility of the soil organic horizons in northwestern Russia. Our specific hypotheses are that: (1) there are several factors, such as climate, soil forming rocks, and land use history, which significantly affect the fertility of soil organic horizons and the vegetation composition in the taiga forests of northwestern Russia, and (2) there are significant relationships between the fertility of soil organic horizons (i.e. content of bio-available nutrients, carbon to nitrogen ratio), on the one hand, and Cajander's forest site types and Sykachev's forest types, identified within the Cajander types, on the other hand, in northwestern Russia.

\section{Materials and methods \\ Study areas}

The 37 Norway spruce ( $P$. abies), 66 Scots pine $(P$. sylvestris), and 16 silver birch ( $B$. pendula) or downy birch (Betula pubescens Ehrh.) plots were established in the northern and middle taiga of the Republic of Karelia (NK and MK respectively) and the Karelian Isthmus (MKI) during the implementation of the International Cooperative Programme on Assessment and Monitoring of Air Pollution Effects on Forests (ICP Forests) in 2008 (Fig. 1). They represent taiga forests of the Northwest Russia at the autonomous positions.

The Republic of Karelia is situated on the Baltic Shield, the Karelian Isthmus at the junction of the Baltic Shield and the Russian Plain. The predominant soil-forming rock in the northern and middle Taiga of Karelia (NK and $\mathrm{MK}$ ) is till (lithified boulder clay); in the Karelian Isthmus (MKI) it is polymictic sandstone (Chertov 1981) - Albic Podzols, Rentic Podzols and Albic Retisols are widely distributed in the area.

The border between the northern and middle taiga is close to the isotherm of 1400 degree days with an average daily temperature above $5^{\circ} \mathrm{C}$. Annual precipitation varies from 555 to $823 \mathrm{~mm}$, being lower in northern taiga. In the Karelian Isthmus precipitation is very high, due to the influence of the sea.

Forests cover $54 \%$ of the Republic of Karelia (Volkov 2008) and about $70 \%$ of the Karelian Isthmus (Doronina 2007). In Karelia, young forests constitute more than $36 \%$ of the forested area, middle-aged (80-120 years) $33 \%$, mature and over-mature, about 30\% (Kryshen 2010). Fire is one of the main factors regulating the 


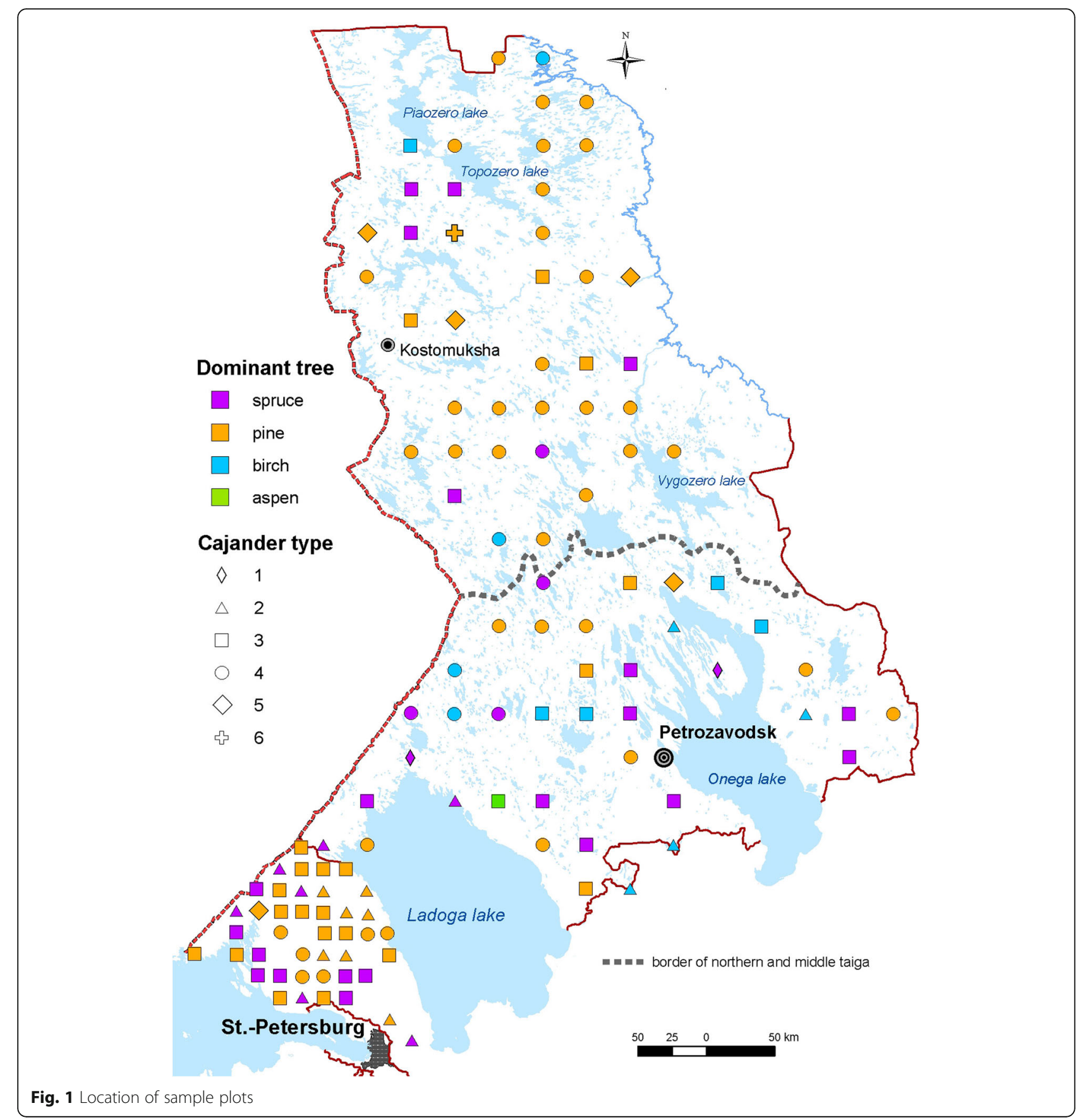

distribution, structure and composition of forests in the study area. In the Republic of Karelia, the forests dominated by pine (P. sylvestris) account for $64 \%$ of the forested area, those dominated by spruce (P. abies) 24\%, birch (B. pendula, B. pubescens) 11\%, and aspen (Populus tremula L.) about $1 \%$. The northern taiga area is dominated by Scots pine forests with dwarf shrubs, green mosses, and lichens, while Norway spruce forests with dwarf shrubs and green mosses are widespread in the middle taiga (Kryshen 2010).
The Karelian Isthmus (MKI) is dominated by pine ( $51 \%$ of the total forest area), while spruce and birch forests are less common there (29\% and 16\% correspondingly; Doronina 2007). Deciduous forests, mainly with $T$. cordata, occur along the shores of the Gulf of Finland and Lake Ladoga, rarely in the central part of the Isthmus (Fedorchuk et al. 2005).

Slash-and-burn agriculture was practiced widely in the Karelian Isthmus until the beginning of the twentieth century. The result was a destruction of spruce forests 
on the most fertile soils. Large-scale and severe fires favored the regeneration of pine. The abandonment of the slash-and-burn practice, selective logging, less frequent forest fires caused an increase of the spruce forest area by 13\% during the period from 1923 to 1983 (Fedorchuk et al. 2005). At the end of World War II, when Finland ceded the western part of the Isthmus to the Soviet Union, the forests received a protected status (Isachenko 2004; Muukkonen 2009; Rautiainen et al. 2016). The slash-and-burn practice had a limited spatial distribution in the Republic of Karelia and the period of implementation was brief (Volkov 2008).

\section{Assessment of plant species cover}

Four rectangular plots of $100 \mathrm{~m}^{2}$ were assessed within the sample plots of the International Co-operative Programme on Assessment and Monitoring of Air Pollution Effects on Forests (ICP Forests). Within each plot, the cover percentage of all plant and lichen species was estimated. Four vegetation layers were identified: a tree layer (woody plants $>5 \mathrm{~m}$ in height), a shrub layer (only woody, between 0.5 and $5 \mathrm{~m}$ height), a herb layer (all non-woody, and woody $<0.5 \mathrm{~m}$ height, including tree seedlings), and a moss-lichen layer (terricolous bryophytes and lichens). In addition, the total cover of each layer and the area of bare soil and litter was estimated.

Cajander's forest site types were identified according to composition of understory vegetation and the occurrence of certain indicator species (Hotanen 2008). The following acronyms for the site types were used: 1) OMaT - Oxalis-Maianthemum, 2) OMT - Oxalis-Myrtillus, 3) MT - Myrtillus, 4) VT - Vaccinium vitisidaea, 5) CT - Calluna, 6) ClT - Cladonia.

Site type 1 presents rich herb vegetation, e.g. Aconitum septentrionale Koelle, Convallaria majalis L., Oxalis acetosella $\mathrm{L}$. and green mosses belonging to the genera Brachythecium and Mnium. Site type 2 is co-dominated by $O$. acetosella and Vaccinium myrtillus L. with a significant addition of mesophilous herb species (including Fragaria vesca L., Maianthemum bifolium (L.) F.W.Schmidt and Rubus saxatilis L.) and boreal green mosses (Hylocomium splendens (Hedw.) Schimp. and Pleurozium schreberi (Willd. ex Brid.) Mitt.). Site type 3 is dominated by $V$. myrtillus and several boreal moss species. Site type 4 is characterized by abundant Vaccinium vitis-idaea $\mathrm{L}$. and $V$. myrtillus. In the northern taiga Empetrum nigrum L. is also quite common, while herb and grass species are rare. The field layer is dominated by $P$. schreberi, some lichen species also occur. In the site types 5 and 6, lichens from the genus Cladonia and $P$. schreberi are very abundant. Calluna vulgaris (L.) Hull is constant in the site type.

Cajander (1909) considered the understory vegetation to be a more sensitive indicator of environmental conditions and potential site productivity than the tree layer (Kuusipalo 1985). The main focus of the Finnish forest type classification is the assessment of the potential productivity of a site, based on the actual vegetation cover, which is considered to reflect invariable site factors. Descriptions of site types are mostly based on undisturbed mature forests (Kuusipalo 1983). Sukachev (1972) developed an alternative concept taking into account the understory vegetation as well as the tree species composition. Concerning the link between the Cajander classification and his own forest typology, Vladimir N. Sukachev wrote: "If we divide the Cajander types according to the tree species composition, these units will mostly match the types that we accepted" (Sukachev 1972, p. 33). In this study Sukachev's forest types dominated by spruce, pine and birch were identified within the Cajander forest site types 2, 3, 4, and 6.

\section{Soil sampling}

Samples of the organic horizon were excavated using a frame of $0.25 \mathrm{~m} \times 0.25 \mathrm{~m}$. At the same site, samples of the $\mathrm{BC} / \mathrm{C}$ horizons were taken from $0.5 \mathrm{~m} \times 0.5 \mathrm{~m}$ holes. The holes were dug in the vicinity of the four vegetation plots. The samples were dried and milled to pass through a 2$\mathrm{mm}$ sieve. The $\mathrm{pH}$ was measured in water and in calcium chloride extracts. Exchangeable potassium (K), calcium $(\mathrm{Ca})$, magnesium $(\mathrm{Mg})$, aluminum $(\mathrm{Al})$, iron $(\mathrm{Fe})$, sodium (Na) were determined by AAS after extraction with 0.1 $\mathrm{mol} \cdot \mathrm{L}^{-1} \mathrm{BaCl}_{2}$, exchangeable acidity - after extraction with $0.1 \mathrm{~mol} \cdot \mathrm{L}^{-1} \mathrm{BaCl}_{2}$. Total metal content in the $\mathrm{C} / \mathrm{BC}$ horizon was determined by AAS after sample decomposition with hydrofluoric acid. Extractable compounds of phosphorous $(\mathrm{P})$ were determined by colorimetry after extraction with aqua regia. Total nitrogen $(\mathrm{N})$ and organic carbon $(\mathrm{C})$ were determined on a CHNS-O analyzer (EA 1110, Italy, CE Instruments).

Effective base saturation was calculated, based on exchangeable base cations and exchangeable acidity values. The particle size distribution was determined gravimetrically for the samples from the $\mathrm{C} / \mathrm{BC}$ horizons. The proportion of the finest particles (clay) is discussed below.

To compare the fertility of the organic horizons in forests, 40 additional samples from the soil organic horizon were taken on the plots with pine and spruce forests in the Lapland reserve of the Murmansk region. These samples were used to provide data on bio-available (ammonium acetate, $\mathrm{pH}=4.65$ ) content of nutrients in the organic horizons of Cajander's Cladonia site type 6.

\section{Stand characteristics}

The following forest parameters were assessed in each sub-plot: basal area (measured with angle gauge from the center of the sub-plot), mean height and mean age assessed for each age class of each tree species. These 
parameters were averaged for the whole sample plot. In addition, breast-height diameter (DBH) was measured for each tree within each sample plot. Based on the measured parameters, the stand density and total wood volume were calculated for each sample plot.

\section{Climatic variables}

Plot-wise values for the sum of effective temperatures (threshold $+5^{\circ} \mathrm{C}$ ) and precipitation for the period of effective temperatures $\left(>+5^{\circ} \mathrm{C}\right)$, and for the whole year, were derived from available spatial models based on the information from 36 meteorological stations of Karelia and six meteorological stations located on the Karelian Isthmus (USSR Climate Reference Book 1965, 19651968; models by Budyko 1971; Polikarpov et al. 1986; Zukert 2000, 2006, 2008). The de Martonne index for humidity was calculated using the following equation:

$H=\mathrm{P} /(T+10)$.

where $P$ is annual precipitation amount $(\mathrm{mm})$, and $T$ annual mean temperature $\left({ }^{\circ} \mathrm{C}\right)$.

\section{Statistical analysis}

Altogether 342 species on 119 plots on the regular grid were used to determine the ordination pattern of vegetation. Non-metric Multidimensional Scaling (NMDS) was performed on log-transformed species abundances (percent of coverage) using the metaMDS function of the vegan package of the $R$ statistical environment ( $R$ Core Team 2018). The Bray-Curtis distances between plots were used for the construction of the ordination diagram. Several sets of variables, such as climatic and forest inventory data, data on soil organic horizons, were fitted as environmental vectors into the NMDS ordination using the function envfit in the vegan package. In addition, 999 random permutations of the variables were performed to assess the significance of the environmental vectors. The goodness of fit statistic was $R^{2}$. In addition, we calculated Pearson's correlation coefficients between climatic, tree stand, soil variables, and species cover and species numbers of different functional groups. The coefficients were calculated for all areas combined.

To identify the influence of forest types on the fertility of the soil organic horizons, v-tests were conducted for each soil variable following Husson et al. (2017). The vtest evaluates a standardized deviation between the mean of a category and the overall mean of a variable. The test examines, whether a variable is characteristic of a category or not. The test statistics is normally distributed under the following null hypothesis: the values of a variable, fitted into a category, are selected at random from all of the possible instances of the variable. This analysis allowed us to find the soil characteristics that are informative and relevant for the sites or the tree species, as well as the exact values of those characteristics.
The v-tests were calculated using the function catdes of the FactoMineR package (Le et al. 2008).

\section{Results \\ Vegetation}

Non-metric Multidimensional Scaling ordination of the vegetation data demonstrated that the plots were distributed in accordance with the fertility level along the main compositional gradient (Fig. 2a). The second gradient shifted from lower to higher latitudes, and separated the forests of the NK, MK and MKI regions.

Sukachev's forest types were identified within the Cajander forest site types in accordance with the tree species composition. Some differences were identified in the total coverage of the different functional groups of ground vegetation throughout the forests dominated by spruce, pine and birch within the most productive Cajander site type 2 (Fig. 2b). Birch forests had the highest coverage of herbs (45.5\%) and the lowest coverage of dwarf shrubs (4.9\%), compared to those of pine and spruce forests. Pine forests had higher cover of herbs (36.0\%), dwarf shrubs (18.6\%), and grasses (6.9\%) compared to spruce forests $(21.6 \%, 8.0 \%, 3.9 \%$, respectively). The abundance of green mosses reached maximum values in spruce forests (25.1\%). Poor light conditions under dense spruce canopy can partly explain the relatively low contribution of herbs and grasses, and high contribution of mosses in forests dominated by spruce. As for the Cajander site type 3 (Fig. 2c), the birch forests had a higher cover of grass and herb species, and a lower cover of green mosses, compared with pine and spruce forests. Dwarf shrubs were more abundant in plots dominated by pine. In spruce forests a relatively high cover of Sphagnum girgensohnii Russow (about 19\%) was found on 6 plots in MKI and on 1 plot in MK. The plots assigned to the Cajander site type 4 (Fig. 2d) were mainly dominated by pine (36 plots), spruce and birch forests were much less common (5 and 4 plots, respectively). There were plots with various disturbances caused by selective cutting and fires. The majority of pine stands of the Cajander's site type 4 were young. A high abundance of $C$. vulgaris is characteristic for pine forests of the Cajander site type 4 plots.

Species density (SR) increased towards the most fertile sites in MK (Fig. 3a). The herb and grass cover, as well as species density increased from the northern to the middle taiga plots (MK and MKI), while the lichen and dwarf shrub cover percentage increased in the NK plots (Fig. 3a).

Dwarf shrubs and herbs correlated most closely with the vegetation patterns (Table 1). The tree ages in the uneven-aged stands in NK varied from 40 to 280 years, in MK from 40 to 160 years, and in MKI from 60 to 140 years. The stand variables (mean height, mean diameter and volume) had a high correlation with the vegetation 

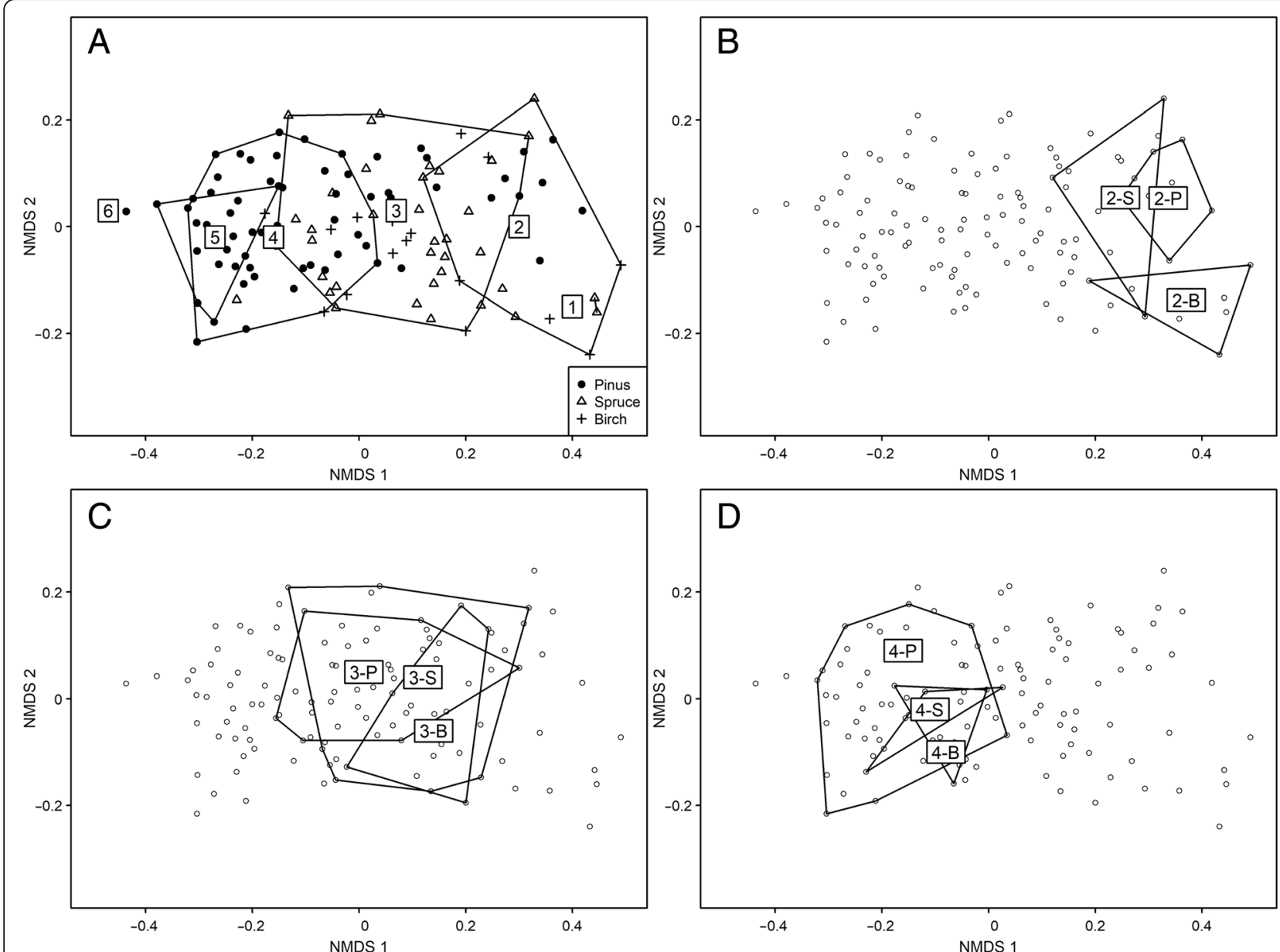

Fig. 2 NMDS ordination of the vegetation data. a) Convex hulls enclose the different Cajander's site types; filled circles, triangles and crosses indicate the position of plots dominated by pine, spruce and birch, respectively. Cajander's forest site types: 1) OMaT - Oxalis-Maianthemum, 2) OMT - Oxalis-Myrtillus, 3) MT - Myrtillus, 4) VT - Vaccinium vitis-idaea, 5) CT - Calluna, 6) CIT - Cladonia. b), c), d): P - pine, S - spruce, B - birch

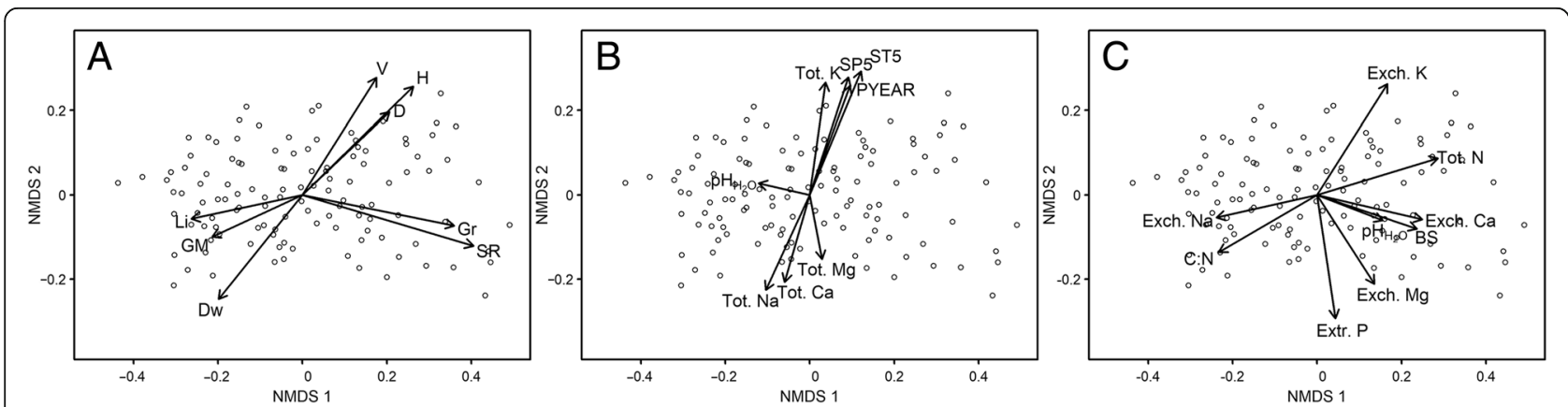

Fig. 3 NMDS ordination of the vegetation data with fitted vectors. Vectors show the direction and strength of the linear correlations of the environmental variables with the plot scores. a) Climatic and BC horizon characteristics: ST5 - sum of effective temperatures, SP5-precipitation at the period of the effective temperatures, PYEAR - total precipitation; $\mathrm{PH}$, total $\mathrm{Ca}$, total $\mathrm{K}$, total $\mathrm{Mg}$, total $\mathrm{Na}$ - characteristics of $\mathrm{BC}$ horizon. b) Functional group covers, species richness and tree stand variables: Li - lichens, GM - green mosses, Dw - dwarf shrubs, Gr - grasses + herbs, SR species density, $\mathrm{V}$ - stand volume, $\mathrm{M}$ - mean height, D - mean diameter. c) The soil organic horizon characteristics, including $\mathrm{C} / \mathrm{N}$ and nutrients 
Table 1 Linear correlations $\left(R^{2}\right)$ with the NMDS ordination pattern

\begin{tabular}{|c|c|c|c|}
\hline & Variable & $R^{2}$ & $P$ \\
\hline \multirow[t]{4}{*}{ Climatic parameters } & Effective temperature sum & 0.612 & 0.001 \\
\hline & Precipitation at the period of the effective $T$ & 0.517 & 0.001 \\
\hline & Average annual temperature & 0.629 & 0.001 \\
\hline & Amount of precipitation per year & 0.458 & 0.001 \\
\hline \multirow[t]{5}{*}{ Plant and lichens cover } & Lichens cover & 0.298 & 0.001 \\
\hline & Green moss cover & 0.229 & 0.001 \\
\hline & Grasses + sedges & 0.208 & 0.001 \\
\hline & Dwarf shrubs & 0.415 & 0.001 \\
\hline & Herbs & 0.554 & 0.001 \\
\hline \multirow[t]{6}{*}{ C/BC horizon characteristics } & $\mathrm{pH} \mathrm{H} \mathrm{H}_{2} \mathrm{O}$ & 0.095 & 0.001 \\
\hline & $\mathrm{pH} \mathrm{CaCl} 2$ & 0.139 & 0.009 \\
\hline & Total Ca & 0.285 & 0.001 \\
\hline & Total Mg & 0.148 & 0.001 \\
\hline & Total K & 0.444 & 0.001 \\
\hline & Total Na & 0.380 & 0.001 \\
\hline \multirow[t]{3}{*}{ Tree stand characteristics } & Height & 0.555 & 0.001 \\
\hline & Diameter & 0.335 & 0.001 \\
\hline & Stand volume & 0.445 & 0.001 \\
\hline \multirow[t]{10}{*}{ Organic soil horizon } & $\mathrm{pH} \mathrm{H} \mathrm{H}_{2} \mathrm{O}$ & 0.070 & 0.016 \\
\hline & $\mathrm{pH} \mathrm{CaCl} 2$ & 0.111 & 0.002 \\
\hline & Total N & 0.223 & 0.001 \\
\hline & $\mathrm{CN}$ & 0.182 & 0.001 \\
\hline & Exchangeable Ca & 0.163 & 0.001 \\
\hline & Exchangeable Mg & 0.157 & 0.001 \\
\hline & Exchangeable K & 0.241 & 0.001 \\
\hline & Exchangeable $\mathrm{Na}$ & 0.149 & 0.001 \\
\hline & Extractable P & 0.218 & 0.001 \\
\hline & $\mathrm{BS}^{\mathrm{a}}$ & 0.156 & 0.001 \\
\hline
\end{tabular}

${ }^{\mathrm{a}}$ Here and in Tables 5, 6, 7, 8 and 9 BS means base saturation

patterns. These variables also tended to increase with increasing site fertility in MKI (Table 1, Fig. 3a).

There was a distinct difference in the proportions of site types within the three regions. In the NK region, the Cajander site type 4 was predominant (67\%), while the site type 3 was also common (23\%). The site type 5 was uncommon in NK (8\%) and occurred very rarely in MK. Only one plot from NK was assigned to site type 6 . The MKI forests were characterized by a prevalence of site type $3(55 \%)$, by a relatively low share of site type 4 $(14 \%)$ and by the highest proportion of site type 2 in all the areas (29\%). The MK forests occupied an intermediate position: site types 3 and 4 had similar proportions, while the share of site type 2 increased significantly compared to NK (16\%); two plots in MK were assigned to site type 1 .
The number of vascular plant species increased considerably from NK to MKI (63 and 160 species, respectively), mainly due to herbs (30 and 101 species) and grasses (9 and 29 species) (Table 2). In NK some species of dwarf shrubs (Ledum palustre L., Vaccinium uliginosum L.) were abundant, while in MK these species occurred mainly in wetlands. Similar features of northern taiga forests were reported from Finland (Tonteri et al. 1990; Salemaa et al. 2008). In the MK and MKI forests some nemoral herb species were recorded (e.g. Aegopodium podagraria L., C. majalis, Hepatica nobilis Mill., Lathyrus vernus (L.) Bernh., Paris quadrifolia L, Pulmonaria obscura Dumort., Stellaria holostea L.). In MKI some species of broadleaved trees and shrubs (Acer platanoides L., Quercus robur L., Corylus avellana L., Lonicera xylosteum L.) occurred. 
Table 2 The functional groups' cover (1) and the number of species (2)

\begin{tabular}{|c|c|c|c|c|c|c|c|c|c|c|c|c|c|}
\hline \multirow{2}{*}{$\begin{array}{l}\text { Cajander's } \\
\text { site type }\end{array}$} & \multirow{2}{*}{$\begin{array}{l}\text { Number } \\
\text { of plots }\end{array}$} & \multicolumn{2}{|c|}{ Dwarf shrubs } & \multicolumn{2}{|c|}{ Herbs } & \multicolumn{2}{|c|}{ Grasses \& sedges } & \multicolumn{2}{|c|}{ Green mosses } & \multicolumn{2}{|c|}{ Sphagnum mosses } & \multicolumn{2}{|c|}{ Lichens } \\
\hline & & 1 & 2 & 1 & 2 & 1 & 2 & 1 & 2 & 1 & 2 & 1 & 2 \\
\hline \multicolumn{14}{|c|}{ Karelia, northern taiga } \\
\hline \multirow[t]{2}{*}{3} & 9 & $47.6^{\mathrm{a}}$ & 4.6 & 5.1 & 7.9 & 1.8 & 3.0 & 57.4 & 8.2 & 6.0 & 1.6 & 0.2 & 1.6 \\
\hline & & $5.2^{\mathrm{b}}$ & 0.6 & 2.2 & 1.6 & 0.3 & 0.4 & 7.2 & 0.8 & 3.2 & 0.5 & 0.1 & 0.4 \\
\hline \multirow[t]{2}{*}{4} & 26 & 50.3 & 5.1 & 1.2 & 3.4 & 1.0 & 1.4 & 47.7 & 6.2 & 1.6 & 0.7 & 11.3 & 3.8 \\
\hline & & 4.1 & 0.2 & 0.4 & 0.5 & 0.4 & 0.2 & 4.5 & 0.4 & 0.7 & 0.2 & 2.8 & 0.4 \\
\hline \multirow[t]{2}{*}{5} & 3 & 43.4 & 6.7 & 2.1 & 2.0 & 0.7 & 1.0 & 33.5 & 6.7 & 11.2 & 2.3 & 39.6 & 6.7 \\
\hline & & 7.9 & 1.5 & 1.8 & 0.6 & 0.4 & 0.6 & 7.1 & 1.2 & 10.7 & 1.2 & 6.5 & 0.9 \\
\hline \multicolumn{14}{|c|}{ Karelia, middle taiga } \\
\hline \multirow[t]{2}{*}{1} & 2 & 8.8 & 1.5 & 57.3 & 30.5 & 7.3 & 6.0 & 28.8 & 14.5 & 0 & 0 & 0 & 1.0 \\
\hline & & 8.2 & 0.5 & 8.2 & 2.5 & 4.5 & 1.0 & 2.2 & 3.5 & 0 & 0 & 0 & 1.0 \\
\hline \multirow[t]{2}{*}{2} & 6 & 6.0 & 2.2 & 40.9 & 28.5 & 5.6 & 6.7 & 21.5 & 15.3 & 13.4 & 2.2 & 0 & 0 \\
\hline & & 1.6 & 0.2 & 12.3 & 2.6 & 1.6 & 0.8 & 6.9 & 1.9 & 8.7 & 1.1 & 0 & 0 \\
\hline \multirow[t]{2}{*}{3} & 16 & 23.6 & 2.3 & 8.1 & 14.9 & 6.1 & 4.5 & 43.9 & 10.9 & 6.0 & 1.5 & 0 & 1.1 \\
\hline & & 2.2 & 0.1 & 1.6 & 1.5 & 1.6 & 0.4 & 5.3 & 0.7 & 2.2 & 0.4 & 0 & 0.3 \\
\hline \multirow[t]{2}{*}{4} & 13 & 34.7 & 4.3 & 1.7 & 5.0 & 2.5 & 2.3 & 63.9 & 9.1 & 2.8 & 1.3 & 7.4 & 5.2 \\
\hline & & 3.7 & 0.5 & 0.4 & 0.7 & 0.8 & 0.3 & 7.2 & 0.7 & 1.7 & 0.3 & 3.5 & 1.0 \\
\hline \multicolumn{14}{|c|}{ Karelian Isthmus, middle taiga } \\
\hline \multirow[t]{2}{*}{2} & 12 & 14.2 & 2.0 & 28.3 & 23.7 & 5.1 & 6.8 & 10.2 & 8.9 & 9.1 & 1.3 & 0 & 0 \\
\hline & & 2.7 & 0.0 & 4.9 & 3.0 & 1.7 & 0.6 & 4.0 & 0.6 & 4.2 & 0.5 & 0 & 0 \\
\hline \multirow[t]{2}{*}{3} & 23 & 21.7 & 2.9 & 9.5 & 10.9 & 7.5 & 5.1 & 29.5 & 7.2 & 18.5 & 1.1 & 0 & 0.4 \\
\hline & & 2.8 & 0.2 & 2.3 & 1.4 & 1.6 & 0.5 & 5.1 & 0.4 & 6.8 & 0.2 & 0 & 0.2 \\
\hline \multirow[t]{2}{*}{4} & 6 & 16.0 & 4.5 & 4.3 & 4.7 & 0.4 & 2.5 & 73.0 & 5.3 & 0 & 0 & 0.6 & 2.3 \\
\hline & & 4.7 & 0.6 & 2.2 & 1.6 & 0.4 & 1.1 & 11.2 & 0.6 & 0 & 0 & 0.2 & 0.5 \\
\hline
\end{tabular}

Here and in Tables 3 and $4:^{\mathrm{a}}-$ mean, $^{\mathrm{b}}$ - standard error

The MK forests were rich with green mosses (52 species) and lichens (23 species), while the MKI forests were poor in cryptogam species: only 7 species of lichens and 5 species of liverworts were found. The number of vascular plants decreased from rich to poor sites, and a similar trend was found for green mosses (Table 2). In general, the middle taiga plots maintained a higher number of vascular plants than the north taiga plots, while the north-taiga sub-xeric and xeric sites (the Cajander site types 5 and 6) had species-rich lichen communities.

\section{Climatic conditions}

The average annual temperature in the north taiga of the Republic of Karelia is close to $0{ }^{\circ} \mathrm{C}$. The Karelian Isthmus and the southern part of Karelia are characterized by a warm and moist climate: the sum of temperatures during the growing period is up to 2000 degrees or more, the average annual temperature can reach $4{ }^{\circ} \mathrm{C}$. The total amount of annual precipitation varies from north to south. In north Karelia it reaches up to 450$500 \mathrm{~mm}$ per year, in south Karelia it is much higher:
600-700 mm per year. In the Karelian Isthmus the amount of precipitation reaches $700-800 \mathrm{~mm}$ due to the influence of the sea .

Of the climatic parameters, the sum of effective temperatures, the average annual temperature and the precipitation for the period of effective temperatures had the highest correlation with the vegetation patterns (Fig. $3 \mathrm{~b}$, Table 1). The sum of effective temperatures ranged from 1372 to 2082 degree days with the lower values in NK and higher values in MKI. The total annual precipitation varied from 555 to $823 \mathrm{~mm}$ with the lower values in NK. The de Martonne index ranged from 44 to 67 , but the variation did not reveal a clear pattern which is typical for this simple ratio.

\section{Soil forming rock and organic horizons}

\section{Total content of chemical elements and proportion of fine} particles in soil forming rock

Among the three regions, distinct differences were found in the total content of $\mathrm{Ca}, \mathrm{Mg}, \mathrm{K}$ and $\mathrm{Na}$ in the lowermost soil horizon $\mathrm{C} / \mathrm{BC}$ (Table 3 ). In the $\mathrm{BC}$ horizons the total content of $\mathrm{K}$ was significantly $(p<0.001)$ higher 
Table 3 BC horizon characteristics

\begin{tabular}{|c|c|c|c|c|c|c|c|c|c|c|c|c|}
\hline \multirow[t]{2}{*}{ Region } & \multirow{2}{*}{$\begin{array}{l}\text { Site type } \\
\text { by } \\
\text { Cajander }\end{array}$} & \multirow{2}{*}{$\begin{array}{l}\text { Proportion } \\
\text { of particles } \\
<0.002\end{array}$} & \multicolumn{2}{|l|}{$\mathrm{pH}$} & \multicolumn{8}{|c|}{ Total content $\left(\mathrm{g} \cdot \mathrm{kg}^{-1}\right)$} \\
\hline & & & $\overline{\mathrm{CaCl}_{2}}$ & $\overline{\mathrm{H}_{2} \mathrm{O}}$ & $\bar{C}$ & $\mathrm{~N}$ & $\mathrm{Ca}$ & $\mathrm{Mg}$ & K & $\mathrm{Na}$ & $\mathrm{Al}$ & $\overline{\mathrm{Fe}}$ \\
\hline \multirow[t]{7}{*}{ Karelia, northern taiga } & \multirow[t]{2}{*}{3} & $1.49^{*}$ & 4.9 & 5.3 & 3.2 & 0.1 & 17.0 & 8.0 & 9.3 & 14.0 & 38 & 17 \\
\hline & & $0.13^{* *}$ & 0.1 & 0.2 & 0.8 & 0.0 & 1.0 & 1.0 & 0.5 & 1.0 & 3 & 2 \\
\hline & \multirow[t]{2}{*}{4} & 1.57 & 5.0 & 5.7 & 4.5 & 0.1 & 17.0 & 6.0 & 8.7 & 14.0 & 42 & 18 \\
\hline & & 0.14 & 0.1 & 0.1 & 1.1 & 0 & 1.0 & 0 & 0.3 & 0 & 1 & 1 \\
\hline & \multirow[t]{2}{*}{5} & 1.57 & 4.5 & 5.5 & 10.1 & 0.1 & 15.0 & 16.0 & 12.0 & 11.0 & 45 & 31 \\
\hline & & 0.02 & 0.6 & 0.3 & 2.3 & 0 & 4.0 & 11.0 & 2.5 & 5.0 & 8 & 21 \\
\hline & 6 & nd & 5.2 & 6.0 & 0.4 & 0.1 & 14.0 & 6.0 & 11.5 & 16.0 & 34 & 12 \\
\hline \multirow[t]{9}{*}{ Karelia, middle taiga } & \multirow[t]{2}{*}{1} & 2.74 & 4.6 & 4.8 & 3.5 & 0.1 & 15.0 & 17.0 & 9.7 & 11.0 & 38 & 25 \\
\hline & & 1.70 & 0.2 & 0.9 & 1.6 & 0.1 & 1.0 & 7.0 & 0.4 & 0 & 1 & 4 \\
\hline & \multirow[t]{2}{*}{2} & 1.06 & 4.4 & 5.1 & 8.7 & 0.1 & 12.0 & 9.0 & 9.8 & 11.0 & 36 & 21 \\
\hline & & 0.13 & 0.2 & 0.3 & 1.6 & 0 & 1.0 & 1.0 & 0.5 & 1.0 & 1 & 5 \\
\hline & \multirow[t]{2}{*}{3} & 1.30 & 4.6 & 5.4 & 7.4 & 0.1 & 12.0 & 9.0 & 10.8 & 12.0 & 38 & 17 \\
\hline & & 0.24 & 0.1 & 0.1 & 1.6 & 0 & 1.0 & 1.0 & 0.4 & 1.0 & 1 & 2 \\
\hline & \multirow[t]{2}{*}{4} & 0.78 & 4.8 & 5.6 & 7.6 & 0.1 & 12.0 & 7.0 & 10.4 & 14.0 & 35 & 16 \\
\hline & & 0.21 & 0.1 & 0.2 & 1.8 & 0 & 1.0 & 1.0 & 0.4 & 1.0 & 1 & 3 \\
\hline & 5 & 0.37 & 5.1 & 5.8 & 1.0 & 0.1 & 12.0 & 3.0 & 11.0 & 15.0 & 32 & 11 \\
\hline \multirow[t]{7}{*}{ Karelian Isthmus, middle taiga } & \multirow[t]{2}{*}{2} & 0.82 & 5.0 & 5.3 & 2.9 & 0 & 11.0 & 6.0 & 13.2 & 9.0 & 36 & 22 \\
\hline & & 0.19 & 0.1 & 0.1 & 0.6 & 0 & 3.0 & 1.0 & 0.7 & 1.0 & 3 & 6 \\
\hline & \multirow[t]{2}{*}{3} & 1.37 & 5.1 & 5.4 & 5.6 & 0 & 9.0 & 5.0 & 15.0 & 9.0 & 39 & 16 \\
\hline & & 0.40 & 0.1 & 0.1 & 1.7 & 0 & 0.0 & 1.0 & 0.6 & 0 & 1 & 1 \\
\hline & \multirow[t]{2}{*}{4} & 0.29 & 5.4 & 5.6 & 1.7 & 0 & 9.0 & 3.0 & 15.8 & 10.0 & 39 & 14 \\
\hline & & 0.08 & 0.2 & 0.1 & 0.6 & 0 & 1.0 & 1.0 & 1.2 & 1.0 & 3 & 4 \\
\hline & 5 & nd & 5.5 & 5.6 & 2.0 & 0 & 9.0 & 3.0 & 20.3 & 14.0 & 39 & 12 \\
\hline
\end{tabular}

* - mean, ${ }^{* *}$ - standard error

while the total content of $\mathrm{Na}$ was lower $(p<0.01)$ in MKI compared to the other two regions, whereas the $\mathrm{Ca}$ content was significantly $(p<0.001)$ higher in NK. The acidity of the $\mathrm{BC}$ horizons in NK was significantly $(p=0.03)$ lower compared to that of MK. An analysis of the data from the three regions demonstrated a higher $(p<0.05)$ proportion of fine particles in the $\mathrm{C} / \mathrm{BC}$ horizons of $\mathrm{NK}$ compared to those in MK and MKI. Total $\mathrm{Ca}, \mathrm{K}$, and $\mathrm{Na}$ in the $\mathrm{C} / \mathrm{BC}$ horizons had the highest correlation with the vegetation patterns, reflecting regional differences.

\section{Organic horizons}

According to Cajander, the soil organic horizons develop in close interaction with the vegetation of boreal forests. The following parameters of the fertility of the organic horizons correlated with the vegetation patterns most closely: total $\mathrm{N}, \mathrm{C} / \mathrm{N}$ ratio, extractable $\mathrm{P}$, exchangeable $\mathrm{Ca}, \mathrm{K}, \mathrm{Mg}$ and base saturation (Fig. 3c, Table 4). The content of total $\mathrm{N}$ and exchangeable $\mathrm{K}$ increased towards the MKI forests, and extractable $\mathrm{P}$ and exchangeable $\mathrm{Mg}$ content increased towards the MK forests, while exchangeable $\mathrm{Ca}$ content increased towards both the MK and MKI plots. The $\mathrm{C} / \mathrm{N}$ ratio increased towards the NK forests.

Table 5 demonstrates differences in fertility between the organic horizons of different Cajander site types in all three regions. The organic horizon of the site type 4 was more acidic with lower content of total $\mathrm{N}$ and base cations, and was characterized by higher $\mathrm{C} / \mathrm{N}$ ratios and lower base saturation compared to site types 3 and 2, while site type 2 was more nutrient rich in the organic horizons with lower acidity compared to other site types.

Comparisons between the subzones/areas taking into account Cajander's site types have demonstrated significant differences in the content of exchangeable $\mathrm{K}$ and total N, which were higher in the organic horizons of site types 3 and 4 in MKI compared to those of NK and MK $(p=0.001-0.0001)$. There were significant $(p<0.05)$ differences in the $\mathrm{C} / \mathrm{N}$ ratio in the organic horizons of site type 3 between NK and MK (33 against 26 respectively). The exchangeable $\mathrm{Na}$ content was significantly higher in the organic horizons of site type 3 and 4 of NK compared to those of MK and MKI $(p=0.001-0.04)$. 
Table 4 Characteristics of the fertility of soil organic horizons in subzones/areas

\begin{tabular}{|c|c|c|c|c|c|c|c|c|c|c|c|c|c|}
\hline \multirow{2}{*}{$\begin{array}{l}\text { Cajander's } \\
\text { site types }\end{array}$} & \multicolumn{2}{|l|}{$\mathrm{pH}$} & \multicolumn{2}{|c|}{ Total $\left(\mathrm{g} \cdot \mathrm{kg}^{-1}\right)$} & \multirow{2}{*}{$\begin{array}{l}\mathrm{C} / \mathrm{N} \\
\text { ratio }\end{array}$} & \multicolumn{6}{|c|}{ Exchangeable $\left(\mathrm{cmol}^{(+)} \cdot \mathrm{kg}^{-1}\right)$} & \multirow{2}{*}{$\begin{array}{l}\text { BS } \\
(\%)\end{array}$} & \multirow{2}{*}{$\begin{array}{l}\text { Extractable } \\
\text { P } \\
\left(\mathrm{mg} \cdot \mathrm{kg}^{-1}\right)\end{array}$} \\
\hline & $\overline{\mathrm{CaCl}_{2}}$ & $\overline{\mathrm{H}_{2} \mathrm{O}}$ & $\bar{C}$ & $\mathrm{~N}$ & & acidity & $\mathrm{Ca}$ & $\mathrm{Mg}$ & $\mathrm{K}$ & $\mathrm{Na}$ & $\overline{\mathrm{Al}}$ & & \\
\hline \multicolumn{14}{|c|}{ Karelia, northern taiga } \\
\hline \multirow[t]{2}{*}{3} & $3.4^{*}$ & 4.4 & 419 & 11.8 & 37 & 4.3 & 12.3 & 2.9 & 2.4 & 0.1 & 0.7 & 80 & 860 \\
\hline & $0.1^{* *}$ & 0.1 & 15 & 0.8 & 3 & 0.3 & 1.1 & 0.5 & 0.1 & 0 & 0.2 & 2 & 44 \\
\hline \multirow[t]{2}{*}{4} & 3.4 & 4.3 & 405 & 9.3 & 46 & 4.6 & 10.8 & 2.4 & 2.2 & 0.2 & 0.9 & 76 & 803 \\
\hline & 0.1 & 0.1 & 13 & 0.4 & 2 & 0.3 & 0.8 & 0.2 & 0.1 & 0 & 0.2 & 2 & 31 \\
\hline \multirow[t]{2}{*}{5} & 3.4 & 4.3 & 403 & 8.4 & 50 & 3.7 & 7.9 & 1.8 & 1.8 & 0.2 & 0.7 & 75 & 730 \\
\hline & 0.1 & 0.1 & 40 & 1.3 & 10 & 0.3 & 1.0 & 0.5 & 0.7 & 0.1 & 0.2 & 3 & 129 \\
\hline 6 & 3.0 & 4.1 & 415 & 5.3 & 78 & 7.1 & 4.8 & 1.6 & 1.6 & 0.2 & 1.9 & 53 & 588 \\
\hline \multicolumn{14}{|c|}{ Karelia, middle taiga } \\
\hline \multirow[t]{2}{*}{1} & 3.9 & 5.0 & 268 & 11.2 & 25 & 2.3 & 14.4 & 3.5 & 1.9 & 0.1 & 0.8 & 89 & 773 \\
\hline & 0.1 & 0.3 & 39 & 3.0 & 3 & 0.5 & 4.5 & 0.5 & 0.6 & 0.0 & 0.6 & 5 & 200 \\
\hline \multirow[t]{2}{*}{2} & 3.9 & 4.8 & 434 & 15.1 & 30 & 3.4 & 21.3 & 5.6 & 2.7 & 0.1 & 0.4 & 88 & 942 \\
\hline & 0.2 & 0.2 & 48 & 1.6 & 3 & 0.7 & 3.4 & 1.8 & 0.4 & 0 & 0.1 & 4 & 93 \\
\hline \multirow[t]{2}{*}{3} & 3.7 & 4.7 & 336 & 10.8 & 37 & 3.7 & 15.8 & 3.8 & 2.3 & 0.1 & 0.7 & 83 & 820 \\
\hline & 0.2 & 0.2 & 29 & 0.8 & 8 & 0.5 & 2.0 & 0.5 & 0.1 & 0 & 0.2 & 3 & 33 \\
\hline \multirow[t]{2}{*}{4} & 3.3 & 4.5 & 351 & 9.0 & 42 & 4.7 & 10.4 & 2.5 & 1.7 & 0.1 & 1.5 & 72 & 671 \\
\hline & 0.2 & 0.2 & 30 & 0.7 & 5 & 0.7 & 1.9 & 0.5 & 0.2 & 0 & 0.4 & 5 & 41 \\
\hline 5 & 3.0 & 4.1 & 495 & 9.4 & 53 & 5.4 & 7.5 & 1.1 & 1.3 & 0.1 & 1.1 & 65 & 682 \\
\hline \multicolumn{14}{|c|}{ Karelian Isthmus, middle taiga } \\
\hline \multirow[t]{2}{*}{2} & 3.5 & 4.4 & 399 & 12.9 & 33 & 4.6 & 14.3 & 2.5 & 3.3 & 0.1 & 1.2 & 81 & 720 \\
\hline & 0.1 & 0.1 & 26 & 1.2 & 3 & 0.7 & 1.1 & 0.3 & 0.2 & 0 & 0.3 & 3 & 51 \\
\hline \multirow[t]{2}{*}{3} & 3.6 & 4.5 & 372 & 12.2 & 32 & 4.2 & 13.5 & 2.4 & 3.1 & 0.1 & 1.5 & 82 & 686 \\
\hline & 0.1 & 0.1 & 18 & 0.6 & 2 & 0.4 & 0.7 & 0.2 & 0.1 & 0 & 0.3 & 2 & 29 \\
\hline \multirow[t]{2}{*}{4} & 3.3 & 4.2 & 416 & 11.2 & 38 & 5.1 & 11.5 & 1.8 & 3.1 & 0.1 & 1.8 & 76 & 612 \\
\hline & 0.1 & 0.1 & 14 & 0.8 & 3 & 0.6 & 1.1 & 0 & 0.2 & 0 & 0.4 & 3 & 25 \\
\hline 5 & 3.4 & 4.3 & 454 & 13.6 & 33 & 3.1 & 12.2 & 1.5 & 2.1 & 0.1 & 0.6 & 84 & 514 \\
\hline
\end{tabular}

* - mean, ** - standard error

The highest content of exchangeable $\mathrm{Mg}$ was found in the organic horizons of site types 2 and 3 of MK compared to those of MKI and NK ( $p=0.02-0.04)$.

A grouping of forests by 3 dominant tree species (pine, birch and spruce) in the three regions without taking into account the ground vegetation, reveals that the organic horizons of pine forests are characterized by the lowest fertility, i.e. the lowest $\mathrm{pH}$ value, the lowest total $\mathrm{N}$ content, the lowest content of extractable $\mathrm{P}$ and base cations, as well as the lowest base saturation, but the highest content of total $\mathrm{C}$ and exchangeable $\mathrm{Al}$ (Table 6). The highest nutrient content, the highest $\mathrm{pH}$ level and a low content of total $\mathrm{C}$ and exchangeable $\mathrm{Al}$ in the organic horizons were found in the birch forests. Spruce forests occupied an intermediate position. The soil organic horizons of the pine forests were characterized by the highest $\mathrm{C} / \mathrm{N}$ ratio (45), while in spruce and birch forests this ratio was significantly lower (30 and 27, respectively).
Table 7 demonstrates the differences in acidity and fertility between the organic horizons based on Sukachev's forest types (within the Cajander system). The organic horizons of pine forests within the Cajander site type 3 have the lowest fertility level, that is, the lowest $\mathrm{pH}$, content and stock of total $\mathrm{N}$, content of extractable $\mathrm{P}$ and exchangeable $\mathrm{Ca}$ and $\mathrm{Mg}$, as well as base saturation, but total $\mathrm{C}$ and exchangeable $\mathrm{Al}$ were highest. Birch forests had the highest nutrient content and a high $\mathrm{pH}$, and the lowest content of total $\mathrm{C}$ and exchangeable $\mathrm{Al}$ in the organic horizons, while spruce forests occupied an intermediate position. The organic horizons of pine forests were also characterized by the highest $\mathrm{C} / \mathrm{N}$ ratio of 44 , while in spruce and birch forests this ratio decreased to 30 and 27 , respectively.

The organic horizons of pine, spruce and birch forests identified within Cajander's site type 2 showed, similar to site type 3 , differences in the acidity and fertility 
Table 5 Characteristics of the fertility of soil organic horizons in Cajander's forest site types

\begin{tabular}{|c|c|c|c|c|c|c|c|c|c|c|c|c|c|c|}
\hline \multirow[t]{2}{*}{ Parameters } & \multicolumn{3}{|l|}{$v$-test } & \multicolumn{3}{|c|}{ Mean in category } & \multicolumn{3}{|c|}{$\begin{array}{l}\text { Standard deviation } \\
\text { in category }\end{array}$} & \multirow[t]{2}{*}{$\begin{array}{l}\text { Overall } \\
\text { mean }\end{array}$} & \multirow{2}{*}{$\begin{array}{l}\text { Overall } \\
\text { standard } \\
\text { deviation }\end{array}$} & \multicolumn{3}{|l|}{$p$-value } \\
\hline & $\begin{array}{l}\mathrm{OMT}^{\mathrm{a}} \\
(n=18)\end{array}$ & $\begin{array}{l}\text { MT } \\
(n=48)\end{array}$ & $\begin{array}{l}\mathrm{VT} \\
(n=45)\end{array}$ & $\begin{array}{l}\text { OMT } \\
(n=18)\end{array}$ & $\begin{array}{l}\text { MT } \\
(n=48)\end{array}$ & $\begin{array}{l}\mathrm{VT} \\
(n=45)\end{array}$ & $\begin{array}{l}\mathrm{OMT} \\
(n=18)\end{array}$ & $\begin{array}{l}\mathrm{MT} \\
(n=48)\end{array}$ & $\begin{array}{l}\mathrm{VT} \\
(n=45)\end{array}$ & & & $\begin{array}{l}\mathrm{OMT} \\
(n=18)\end{array}$ & $\begin{array}{l}\mathrm{MT} \\
(n=48)\end{array}$ & $\begin{array}{l}\mathrm{VT} \\
(n=45)\end{array}$ \\
\hline$\overline{\mathrm{pH} \mathrm{CaCl}}$ & 1.59 & 1.79 & -2.72 & 3.67 & 3.60 & 3.35 & 0.52 & 0.54 & 0.37 & 3.51 & 0.48 & 0.113 & 0.073 & 0.006 \\
\hline $\mathrm{pH} \mathrm{H} \mathrm{H}_{2} \mathrm{O}$ & 0.55 & 1.57 & -1.82 & 4.52 & 4.55 & 4.36 & 0.50 & 0.53 & 0.41 & 4.46 & 0.48 & 0.583 & 0.116 & 0.069 \\
\hline Total C $\left(\mathrm{g} \cdot \mathrm{kg}^{-1}\right)$ & 1.32 & -1.60 & 0.59 & 411 & 369 & 391 & 98.6 & 93.2 & 79.9 & 385 & 89 & 0.188 & 0.109 & 0.558 \\
\hline Total N $\left(\mathrm{g} \cdot \mathrm{kg}^{-1}\right)$ & 3.76 & 1.88 & -4.00 & 13.7 & 11.7 & 9.4 & 3.95 & 2.97 & 2.31 & 11.0 & 3.27 & 0 & 0.060 & 0 \\
\hline $\mathrm{C} / \mathrm{N}$ & -2 & -2 & 3 & 32 & 34 & 44 & 10 & 19 & 13 & 38 & 16 & 0.062 & 0.037 & 0.005 \\
\hline $\begin{array}{l}\text { Exchangeable } \\
\text { acidity }^{\mathrm{b}}\end{array}$ & -0.28 & -1.18 & 1.72 & 4.19 & 4.06 & 4.68 & 2.12 & 1.78 & 1.86 & 4.31 & 1.86 & 0.781 & 0.237 & 0.086 \\
\hline $\begin{array}{l}\text { Exchangeable } \\
\mathrm{Ca}^{\mathrm{b}}\end{array}$ & 3.02 & 1.83 & -3.21 & 16.6 & 14.1 & 10.8 & 6.38 & 5.39 & 4.71 & 12.9 & 5.66 & 0.003 & 0.067 & 0.001 \\
\hline $\begin{array}{l}\text { Exchangeable } \\
\mathrm{Mg}^{\mathrm{b}}\end{array}$ & 2.02 & 1.03 & -1.97 & 3.52 & 2.95 & 2.34 & 2.88 & 1.61 & 1.24 & 2.74 & 1.75 & 0.043 & 0.301 & 0.049 \\
\hline $\begin{array}{l}\text { Exchangeable } \\
\mathrm{K}^{\mathrm{b}}\end{array}$ & 3.41 & 2.55 & -3.66 & 3.08 & 2.72 & 2.16 & 0.88 & 0.64 & 0.63 & 2.50 & 0.78 & 0.001 & 0.011 & 0 \\
\hline $\begin{array}{l}\text { Exchangeable } \\
\mathrm{Na}^{\mathrm{b}}\end{array}$ & -0.78 & -2.18 & 2.33 & 0.11 & 0.10 & 0.13 & 0.04 & 0.05 & & 0.12 & 0.06 & 0.432 & 0.029 & 0.020 \\
\hline $\begin{array}{l}\text { Exchangeable } \\
\mathrm{Al}^{\mathrm{b}}\end{array}$ & -0.55 & -0.07 & 0.70 & 0.95 & 1.07 & 1.16 & 0.82 & 1.20 & 1.06 & 1.08 & 1.05 & 0.586 & 0.946 & 0.482 \\
\hline $\begin{array}{l}\text { Exchangeable } \\
\mathrm{Mn}^{\mathrm{b}}\end{array}$ & 1.06 & 0.80 & -1.38 & 1.08 & 1.00 & 0.86 & 0.58 & 0.58 & 0.49 & 0.95 & 0.54 & 0.287 & 0.422 & 0.169 \\
\hline BS (\%) & 1.84 & 2.22 & -3.17 & 83.4 & 81.7 & 74.6 & 9.5 & 9.2 & 12.6 & 78.9 & 11.4 & 0.066 & 0.026 & 0.002 \\
\hline $\begin{array}{l}\text { Extractable P } \\
\left(\mathrm{mg} \cdot \mathrm{kg}^{-1}\right)\end{array}$ & 1.08 & 0.40 & -0.73 & 794 & 763 & 739 & 217 & 153 & 164 & 754 & 170 & 0.282 & 0.623 & 0.468 \\
\hline
\end{tabular}

${ }^{\mathrm{a} O M T}$ - Oxalis-Myrtillus, MT - Myrtillus, VT - Vaccinium vitis-idaea; ${ }^{\mathrm{b}}-\mathrm{cmol}(+) \cdot \mathrm{kg}^{-1}$

characteristics (Table 7). Site type 4 was mainly dominated by Scots pine, and results of v-tests demonstrated that the organic horizons of the pine forests were poor in nutrients as in the site types 2 and 3 .

The more detailed soil sampling within Cajander's site type 6 (Cladonia) in the Lapland reserve (Murmansk region) demonstrated that if one considers micro-zones below the crowns, the organic horizons contained significantly more bio-available nutrients in forests dominated by spruce compared to those dominated by pine (Fig. 4). There were significant differences in the content of soil nutrients below and between the crowns in forests dominated by spruce. The nutrient content in the soil organic horizons of the two micro-zones a) close to tree trunks and b) below the crowns of spruce trees, was significantly higher than the nutrient content in the soil organic horizons between the crowns.

Thus, there were significant differences in the fertility of soil organic horizons between Sukachev's forest types dominated by different tree species within the same Cajander forest site types. The forests, dominated by spruce and birch are characterized by more fertile organic horizons than those dominated by pine within the same Cajander site type. Therefore, along with the ground vegetation, taking into account the predominance of tree species is of great importance for the assessment of relationships between the fertility of soil organic horizons and the vegetation.

\section{Correlations between the total content of elements in soil forming rock and their exchangeable forms in the organic horizons}

When analyzing data from all three areas together, there was no close correlation found between the total content of $\mathrm{Ca}$ in the $\mathrm{BC}$ horizons, on the one hand, and exchangeable $\mathrm{Ca}$ content in the organic horizons, on the other hand. Positive close correlations were found between the total content of $\mathrm{Mg}$ and $\mathrm{K}$ in the $\mathrm{BC}$ horizons and content of their exchangeable forms in the organic horizons $(r=0.400$ and 0.331 respectively). The variation in exchangeable $\mathrm{Mg}$ and $\mathrm{K}$ in the organic horizons could be partly explained by their total content in the soil forming rock, but this was not possible for exchangeable $\mathrm{Ca}$.

\section{Discussion}

Effects of soil forming rock and land use history on site fertility

Compared to other areas, a comparable or even higher content of exchangeable $\mathrm{Ca}$ in the organic horizons of 
Table 6 Characteristics of the fertility of soil organic horizons in pine, spruce and birch forests

\begin{tabular}{|c|c|c|c|c|c|c|c|c|c|c|c|c|c|c|}
\hline \multirow[t]{2}{*}{ Parameters } & \multicolumn{3}{|l|}{$v$-test } & \multicolumn{3}{|c|}{ Mean in category } & \multicolumn{3}{|c|}{$\begin{array}{l}\text { Standard deviation in } \\
\text { category }\end{array}$} & \multirow[t]{2}{*}{$\begin{array}{l}\text { Overall } \\
\text { mean }\end{array}$} & \multirow{2}{*}{$\begin{array}{l}\text { Overall } \\
\text { standard } \\
\text { deviation }\end{array}$} & \multicolumn{3}{|l|}{$p$-value } \\
\hline & $\begin{array}{l}\text { pine } \\
(n=66)\end{array}$ & $\begin{array}{l}\text { spruce } \\
(n=37)\end{array}$ & $\begin{array}{l}\text { birch } \\
(n=16)\end{array}$ & $\begin{array}{l}\text { pine } \\
(n=66)\end{array}$ & $\begin{array}{l}\text { spruce } \\
(n=37)\end{array}$ & $\begin{array}{l}\text { birch } \\
(n=16)\end{array}$ & $\begin{array}{l}\text { pine } \\
(n=66)\end{array}$ & $\begin{array}{l}\text { spruce } \\
(n=37)\end{array}$ & $\begin{array}{l}\text { birch } \\
(n=16)\end{array}$ & & & $\begin{array}{l}\text { pine } \\
(n=66)\end{array}$ & $\begin{array}{l}\text { spruce } \\
(n=37)\end{array}$ & $\begin{array}{l}\text { birch } \\
(n=16)\end{array}$ \\
\hline $\mathrm{pH} \mathrm{CaCl} 2$ & -4.48 & 1.18 & 4.93 & 3.33 & 3.58 & 4.06 & 0.36 & 0.43 & 0.56 & 3.51 & 0.48 & 0 & 0.237 & 0 \\
\hline $\mathrm{pH} \mathrm{H} \mathrm{H}_{2} \mathrm{O}$ & -3.83 & 0.60 & 4.77 & 4.31 & 4.50 & 4.99 & 0.37 & 0.44 & 0.58 & 4.46 & 0.48 & 0 & 0.548 & 0 \\
\hline $\begin{array}{l}\text { Total C }\left(\mathrm{g} \cdot \mathrm{kg}^{-}\right. \\
\left.{ }^{1}\right)\end{array}$ & 3.22 & -1.33 & -2.88 & 409 & 369 & 325 & 72 & 89 & 119 & 385 & 89.22 & 0.001 & 0.183 & 0.004 \\
\hline Total N $\left(\mathrm{g} \cdot \mathrm{kg}^{-1}\right)$ & -4.49 & 3.73 & 1.48 & 9.8 & 12.6 & 12.1 & 2.76 & 3.20 & 3.46 & 11.0 & 3.27 & 0 & 0 & 0.140 \\
\hline $\mathrm{C} / \mathrm{N}$ & 5 & -3 & -3 & 45 & 30 & 27 & 18 & 8 & 9 & 38 & 16 & 0 & 0 & 0.003 \\
\hline $\begin{array}{l}\text { Exchangeable } \\
\text { acidity }^{\mathrm{a}}\end{array}$ & 4.25 & -2.00 & -3.49 & 4.96 & 3.80 & 2.79 & 1.80 & 1.58 & 1.49 & 4.31 & 1.86 & 0 & 0.046 & 0 \\
\hline $\begin{array}{l}\text { Exchangeable } \\
\mathrm{Ca}^{\mathrm{a}}\end{array}$ & -4.96 & 2.74 & 3.52 & 10.6 & 15.0 & 17.5 & 3.98 & 5.49 & 7.3 & 12.9 & 5.66 & 0 & 0.006 & 0 \\
\hline $\begin{array}{l}\text { Exchangeable } \\
\mathrm{Mg}^{\mathrm{a}}\end{array}$ & -4.51 & 0.87 & 5.39 & 2.09 & 2.95 & 4.95 & 1.03 & 1.36 & 2.81 & 2.74 & 1.75 & 0 & 0.385 & 0 \\
\hline $\begin{array}{l}\text { Exchangeable } \\
\mathrm{K}^{\mathrm{a}}\end{array}$ & -1.72 & 0.77 & 1.46 & 2.39 & 2.58 & 2.76 & 0.78 & 0.71 & 0.90 & 2.50 & 0.78 & 0.085 & 0.439 & 0.145 \\
\hline $\begin{array}{l}\text { Exchangeable } \\
\mathrm{Na}^{\mathrm{a}}\end{array}$ & 2.45 & -1.01 & -2.20 & 0.13 & 0.11 & 0.09 & 0.06 & 0.06 & 0.05 & 0.12 & 0.06 & 0.014 & 0.313 & 0.028 \\
\hline $\begin{array}{l}\text { Exchangeable } \\
\mathrm{Al}^{\mathrm{a}}\end{array}$ & 3.13 & -1.37 & -2.70 & 1.35 & 0.88 & 0.41 & 1.24 & 0.66 & 0.33 & 1.08 & 1.05 & 0.002 & 0.171 & 0.007 \\
\hline $\begin{array}{l}\text { Exchangeable } \\
\mathrm{Mn}^{\mathrm{a}}\end{array}$ & -3.07 & 1.94 & 1.85 & 0.81 & 1.09 & 1.18 & 0.48 & 0.56 & 0.59 & 0.95 & 0.54 & 0.002 & 0.053 & 0.065 \\
\hline BS (\%) & -5.21 & 2.69 & 3.94 & 74.0 & 83.0 & 89.4 & 11.0 & 9.0 & 6.4 & 78.9 & 11.4 & 0 & 0.007 & 0 \\
\hline $\begin{array}{l}\text { Extractable P } \\
\left(\mathrm{mg} \cdot \mathrm{kg}^{-1}\right)\end{array}$ & -3.88 & 2.58 & 2.16 & 700 & 814 & 840 & 127 & 184 & 215 & 754 & 170 & 0 & 0.010 & 0.031 \\
\hline
\end{tabular}

MKI where total content of $\mathrm{Ca}$ in $\mathrm{BC}$ horizons was significantly lower than in NK and MK, could be explained by the land-use history (Muukkonen et al. 2009; Rautiainen et al. 2016). Slash-and-burn and amelioration practices in previous times probably contributed significantly to the current soil nutrient status, resulting in the unexpected high exchangeable Ca content in the organic horizons in MKI. Previous land-use practices focusing on soil fertility improvement in the Karelian Isthmus thus resulted in higher exchangeable $\mathrm{Ca}$ in the organic horizons. This effect, together with more favorable climatic conditions, may explain the higher stand productivity in MKI compared to NK and MK.

\section{Climatic factors and vegetation}

The influence of climatic factors on the soil organic horizon fertility could be mediated by vegetation, i.e. by the predominance of certain species within the forest site types and by the proportion of site types within the regions. These proportions could be explained by differences in the climatic conditions as well as by the reactions of forests developing under different climatic conditions under previous land-use practice and human disturbances, including fire and timber harvesting.
Close correlations between plant species richness and cover and climatic factors were found in different plant functional groups (Tables 8, 9). The herb and grass species richness and cover correlated positively with temperature and total precipitation. Negative correlations with these climate variables were found for lichens and dwarf shrubs.

Close correlations were also found between the species richness and plant cover of functional species groups and the parameters related to stand productivity. These correlations increased in MKI, where the sum of effective temperatures and precipitation were highest. The number of herb and grass species correlated positively, and species number of dwarf shrubs and lichens correlated negatively, with tree height and stand volume. Thus, the influence of climatic factors on vegetation in the study areas is evident.

The same climatic factors were closely related to the fertility characteristics of the organic horizon, such as content of exchangeable $\mathrm{K}(p<0.005)$, exchangeable $\mathrm{Ca}$ $(p<0.01)$ and total $\mathrm{N}(p<0.01)$ as well as $\mathrm{C}$ to $\mathrm{N}$ ratio $(p<0.008)$. These variables, in turn, were closely associated with richness and cover of plant species and functional groups (Tables 8,9 ). This result can be explained 
Table 7 Characteristics of the fertility of soil organic horizons in Sukachev's forest types within the Cajander's forest site types $2-4$

\begin{tabular}{|c|c|c|c|c|c|c|c|c|c|c|c|c|c|c|}
\hline \multirow[t]{2}{*}{ Parameters } & \multicolumn{3}{|l|}{ v-test } & \multicolumn{3}{|c|}{ Mean in category } & \multicolumn{3}{|c|}{$\begin{array}{l}\text { Standard deviation in } \\
\text { category }\end{array}$} & \multirow[t]{2}{*}{$\begin{array}{l}\text { Overall } \\
\text { mean }\end{array}$} & \multirow{2}{*}{$\begin{array}{l}\text { Overall } \\
\text { standard } \\
\text { deviation }\end{array}$} & \multicolumn{3}{|l|}{ p-value } \\
\hline & $\begin{array}{l}\text { pine } \\
(n=66)\end{array}$ & $\begin{array}{l}\text { spruce } \\
(n= \\
37)\end{array}$ & $\begin{array}{l}\text { birch } \\
(n=16)\end{array}$ & $\begin{array}{l}\text { pine } \\
(n=66)\end{array}$ & $\begin{array}{l}\text { spruce } \\
(n= \\
37)\end{array}$ & $\begin{array}{l}\text { birch } \\
(n=16)\end{array}$ & $\begin{array}{l}\text { pine } \\
(n=66)\end{array}$ & $\begin{array}{l}\text { spruce } \\
(n= \\
37)\end{array}$ & $\begin{array}{l}\text { birch } \\
(n=16)\end{array}$ & & & $\begin{array}{l}\text { pine } \\
(n=66)\end{array}$ & $\begin{array}{l}\text { spruce } \\
(n= \\
37)\end{array}$ & $\begin{array}{l}\text { birch } \\
(n=16)\end{array}$ \\
\hline \multicolumn{15}{|c|}{ 2-OMT (pine $n=7$, spruce $n=7$, birch $n=4$ ) } \\
\hline $\mathrm{pH} \mathrm{CaCl} 2$ & -1.62 & 0.16 & 1.71 & 3.42 & 3.70 & 4.08 & 0.57 & 0.40 & 0.44 & 3.67 & 0.52 & 0.105 & 0.872 & 0.087 \\
\hline $\mathrm{pH} \mathrm{H} \mathrm{H}_{2} \mathrm{O}$ & -0.89 & -0.75 & 1.93 & 4.38 & 4.40 & 4.96 & 0.61 & 0.24 & 0.50 & 4.52 & 0.50 & 0.372 & 0.452 & 0.054 \\
\hline Total C $\left(\mathrm{g} \cdot \mathrm{kg}^{-1}\right)$ & 0.54 & 0.54 & 0.43 & 427 & 427 & 430 & 107 & 107 & 37.13 & 411 & 99 & 0.590 & 0.590 & 0.667 \\
\hline Total N $\left(\mathrm{g} \cdot \mathrm{kg}^{-1}\right)$ & 1.88 & 1.88 & 0.82 & 15.9 & 15.9 & 15.1 & 2.00 & 2.00 & 4.70 & 13.66 & 3.95 & 0.060 & 0.060 & 0.410 \\
\hline $\mathrm{C} / \mathrm{N}$ & 2 & -2 & 0 & 37 & 27 & 30 & 11 & 6 & 8 & 32 & 10 & 0.054 & 0.102 & 0.730 \\
\hline $\begin{array}{l}\text { Exchangeable } \\
\text { acidity }^{\mathrm{a}}\end{array}$ & 1.47 & -0.83 & -0.75 & 5.14 & 3.66 & 3.47 & 2.83 & 1.31 & 1.60 & 4.19 & 2.12 & 0.141 & 0.405 & 0.453 \\
\hline $\begin{array}{l}\text { Exchangeable } \\
\mathrm{Ca}^{\mathrm{a}}\end{array}$ & -2.41 & 0.77 & 1.92 & 12.0 & 18.1 & 22.2 & 1.33 & 5.97 & 7.64 & 16.6 & 6.38 & 0.016 & 0.443 & 0.054 \\
\hline $\begin{array}{l}\text { Exchangeable } \\
\mathrm{Mg}^{\mathrm{a}}\end{array}$ & -1.67 & -0.67 & 2.74 & 2.06 & 2.93 & 7.09 & 0.44 & 1.66 & 4.26 & 3.52 & 2.88 & 0.095 & 0.503 & 0.006 \\
\hline Exchangeable $\mathrm{K}^{\mathrm{a}}$ & 0.47 & -0.93 & 0.54 & 3.20 & 2.83 & 3.29 & 1.05 & 0.86 & 0.68 & 3.08 & 0.88 & 0.641 & 0.355 & 0.591 \\
\hline $\begin{array}{l}\text { Exchangeable } \\
\mathrm{Na}^{\mathrm{a}}\end{array}$ & -0.15 & 1.01 & -1.00 & 0.11 & 0.12 & 0.09 & 0.03 & 0.04 & 0.05 & 0.11 & 0.04 & 0.879 & 0.314 & 0.317 \\
\hline $\begin{array}{l}\text { Exchangeable } \\
\mathrm{Al}^{\mathrm{a}}\end{array}$ & 2.10 & -0.45 & -1.94 & 1.47 & 0.84 & 0.23 & 1.05 & 0.33 & 0.07 & 0.95 & 0.82 & 0.036 & 0.652 & 0.053 \\
\hline $\begin{array}{l}\text { Exchangeable } \\
\mathrm{Mn}^{\mathrm{a}}\end{array}$ & -2.71 & 0.60 & 2.48 & 0.60 & 1.18 & 1.73 & 0.30 & 0.46 & 0.41 & 1.08 & 0.58 & 0.007 & 0.549 & 0.013 \\
\hline BS (\%) & -1.95 & 0.68 & 1.48 & 77.8 & 85.4 & 89.8 & 10.6 & 7.71 & 5.64 & 83.4 & 9.54 & 0.052 & 0.494 & 0.139 \\
\hline $\begin{array}{l}\text { Extractable P } \\
\left(\mathrm{mg} \cdot \mathrm{kg}^{-1}\right)\end{array}$ & -2.69 & 0.72 & 2.31 & 616 & 842 & 1022 & 108 & 140 & 238 & 794 & 217 & 0.007 & 0.470 & 0.021 \\
\hline \multicolumn{15}{|c|}{ 3-MT (pine $n=17$, spruce $n=23$, birch $n=8$ ) } \\
\hline $\mathrm{pH} \mathrm{CaCl} 2$ & -2.14 & -0.23 & 3.06 & 3.38 & 3.58 & 4.14 & 0.38 & 0.44 & 0.74 & 3.60 & 0.54 & 0.032 & 0.818 & 0.002 \\
\hline $\mathrm{pH} \mathrm{H} \mathrm{H}_{2} \mathrm{O}$ & -1.96 & -0.20 & 2.79 & 4.34 & 4.53 & 5.02 & 0.31 & 0.49 & 0.72 & 4.55 & 0.53 & 0.050 & 0.839 & 0.005 \\
\hline Total C $\left(g \cdot \mathrm{kg}^{-1}\right)$ & 2.37 & -0.66 & -2.16 & 412 & 360 & 303 & 75.5 & 84.5 & 115 & 369 & 93.2 & 0.018 & 0.510 & 0.031 \\
\hline Total N $\left(\mathrm{g} \cdot \mathrm{kg}^{-1}\right)$ & -1.68 & 1.84 & -0.31 & 10.7 & 12.5 & 11.4 & 3.36 & 2.78 & 2.11 & 11.7 & 2.97 & 0.093 & 0.066 & 0.753 \\
\hline $\mathrm{C} / \mathrm{N}$ & 3 & -2 & -1 & 44 & 30 & 27 & 27 & 8 & 10 & 34 & 19 & 0.007 & 0.094 & 0.219 \\
\hline $\begin{array}{l}\text { Exchangeable } \\
\text { acidity }\end{array}$ & 2.44 & -0.82 & -2.04 & 4.92 & 3.84 & 2.87 & 1.79 & 1.63 & 1.46 & 4.06 & 1.78 & 0.015 & 0.414 & 0.041 \\
\hline $\begin{array}{l}\text { Exchangeable } \\
\mathrm{Ca}\end{array}$ & -2.15 & 0.73 & 1.78 & 11.8 & 14.7 & 17.2 & 3.13 & 5.09 & 8.14 & 14.1 & 5.39 & 0.031 & 0.465 & 0.074 \\
\hline $\begin{array}{l}\text { Exchangeable } \\
\text { Mg }\end{array}$ & -2.76 & 0.53 & 2.83 & 2.07 & 3.08 & 4.44 & 0.92 & 1.42 & 2.18 & 2.95 & 1.61 & 0.006 & 0.596 & 0.005 \\
\hline Exchangeable $\mathrm{K}$ & -0.54 & 0.27 & 0.33 & 2.65 & 2.75 & 2.79 & 0.61 & 0.55 & 0.93 & 2.72 & 0.64 & 0.592 & 0.789 & 0.742 \\
\hline $\begin{array}{l}\text { Exchangeable } \\
\mathrm{Na}\end{array}$ & 0.78 & 0.11 & -1.15 & 0.11 & 0.11 & 0.09 & 0.04 & 0.05 & 0.04 & 0.10 & 0.05 & 0.436 & 0.910 & 0.250 \\
\hline Exchangeable Al & 2.33 & -1.27 & -1.30 & 1.62 & 0.84 & 0.56 & 1.70 & 0.73 & 0.42 & 1.07 & 1.20 & 0.020 & 0.205 & 0.195 \\
\hline $\begin{array}{l}\text { Exchangeable } \\
\mathrm{Mn}\end{array}$ & -1.35 & 1.18 & 0.15 & 0.85 & 1.10 & 1.03 & 0.57 & 0.58 & 0.57 & 1.00 & 0.58 & 0.177 & 0.238 & 0.879 \\
\hline BS (\%) & -2.83 & 1.14 & 2.11 & 76.5 & 83.3 & 88.0 & 9.11 & 8.07 & 7.69 & 81.7 & 9.23 & 0.005 & 0.254 & 0.035 \\
\hline $\begin{array}{l}\text { Extractable } P \\
\left(\mathrm{mg}^{\circ} \mathrm{kg}^{-1}\right)\end{array}$ & -2.04 & 1.50 & 0.61 & 702 & 798 & 794 & 99 & 183 & 127 & 763 & 153 & 0.041 & 0.134 & 0.541 \\
\hline \multicolumn{15}{|c|}{$4-\mathrm{VT}$ (pine $n=36$, spruce $n=5$, birch $n=4$ ) } \\
\hline $\mathrm{pHCaCl} 2$ & -1.94 & -0.21 & 2.96 & 3.30 & 3.32 & 3.88 & 0.32 & 0.49 & 0.17 & 3.35 & 0.37 & 0.052 & 0.835 & 0.003 \\
\hline $\mathrm{pH} \mathrm{H}{ }_{2} \mathrm{O}$ & -2.01 & -0.19 & 3.04 & 4.30 & 4.33 & 4.97 & 0.36 & 0.42 & 0.44 & 4.36 & 0.41 & 0.044 & 0.848 & 0.002 \\
\hline
\end{tabular}


Table 7 Characteristics of the fertility of soil organic horizons in Sukachev's forest types within the Cajander's forest site types $2-4$ (Continued)

\begin{tabular}{|c|c|c|c|c|c|c|c|c|c|c|c|c|c|c|}
\hline \multirow[t]{2}{*}{ Parameters } & \multicolumn{3}{|l|}{$v$-test } & \multicolumn{3}{|c|}{ Mean in category } & \multicolumn{3}{|c|}{$\begin{array}{l}\text { Standard deviation in } \\
\text { category }\end{array}$} & \multirow[t]{2}{*}{$\begin{array}{l}\text { Overall } \\
\text { mean }\end{array}$} & \multirow{2}{*}{$\begin{array}{l}\text { Overall } \\
\text { standard } \\
\text { deviation }\end{array}$} & \multicolumn{3}{|l|}{$p$-value } \\
\hline & $\begin{array}{l}\text { pine } \\
(n=66)\end{array}$ & $\begin{array}{l}\text { spruce } \\
(n= \\
37)\end{array}$ & $\begin{array}{l}\text { birch } \\
(n=16)\end{array}$ & $\begin{array}{l}\text { pine } \\
(n=66)\end{array}$ & $\begin{array}{l}\text { spruce } \\
(n= \\
37)\end{array}$ & $\begin{array}{l}\text { birch } \\
(n=16)\end{array}$ & $\begin{array}{l}\text { pine } \\
(n=66)\end{array}$ & $\begin{array}{l}\text { spruce } \\
(n= \\
37)\end{array}$ & $\begin{array}{l}\text { birch } \\
(n=16)\end{array}$ & & & $\begin{array}{l}\text { pine } \\
(n=66)\end{array}$ & $\begin{array}{l}\text { spruce } \\
(n= \\
37)\end{array}$ & $\begin{array}{l}\text { birch } \\
(n=16)\end{array}$ \\
\hline Total C $\left(\mathrm{g} \cdot \mathrm{kg}^{-1}\right)$ & 2.87 & -0.64 & -3.33 & 408 & 369 & 263 & 63 & 48 & 132 & 391 & 79.9 & 0.004 & 0.524 & 0.001 \\
\hline Total $\left(\mathrm{Ng} \mathrm{kg}^{-1}\right)$ & -0.66 & -0.08 & 1.02 & 9.31 & 9.35 & 10.6 & 2.23 & 2.44 & 3.20 & 9.43 & 2.31 & 0.510 & 0.934 & 0.309 \\
\hline $\mathrm{C} / \mathrm{N}$ & 3 & -0.5 & -3 & 46 & 41 & 24 & 12 & 7 & 7 & 44 & 13 & 0.009 & 0.626 & 0.002 \\
\hline $\begin{array}{l}\text { Exchangeable } \\
\text { acidity }\end{array}$ & 2.45 & -0.35 & -3.05 & 5.03 & 4.40 & 1.94 & 1.66 & 1.92 & 1.43 & 4.68 & 1.86 & 0.014 & 0.725 & 0.002 \\
\hline $\begin{array}{l}\text { Exchangeable } \\
\mathrm{Ca}\end{array}$ & -1.61 & 0.92 & 1.25 & 10.2 & 12.6 & 13.6 & 4.62 & 6.33 & 1.54 & 10.8 & 4.71 & 0.108 & 0.360 & 0.213 \\
\hline $\begin{array}{l}\text { Exchangeable } \\
\text { Mg }\end{array}$ & -1.56 & -0.27 & 2.49 & 2.19 & 2.19 & 3.83 & 1.21 & 0.65 & 1.33 & 2.34 & 1.24 & 0.119 & 0.785 & 0.013 \\
\hline Exchangeable $\mathrm{K}$ & 1.09 & -1.46 & 0.08 & 2.22 & 1.77 & 2.19 & 0.63 & 0.43 & 0.85 & 2.16 & 0.63 & 0.276 & 0.145 & 0.938 \\
\hline $\begin{array}{l}\text { Exchangeable } \\
\mathrm{Na}\end{array}$ & 0.88 & 0.22 & -1.48 & 0.14 & 0.14 & 0.09 & 0.06 & 0.08 & 0.08 & 0.13 & 0.06 & 0.381 & 0.825 & 0.140 \\
\hline $\begin{array}{l}\text { Exchangeable } \\
\text { Al }\end{array}$ & 1.21 & 0.02 & -1.72 & 1.26 & 1.17 & 0.29 & 1.12 & 0.76 & 0.07 & 1.16 & 1.06 & 0.228 & 0.986 & 0.086 \\
\hline $\begin{array}{l}\text { Exchangeable } \\
\mathrm{Mn}\end{array}$ & -0.31 & 0.04 & 0.39 & 0.85 & 0.87 & 0.96 & 0.49 & 0.61 & 0.53 & 0.86 & 0.49 & 0.757 & 0.968 & 0.696 \\
\hline BS (\%) & -2.25 & 0.35 & 2.78 & 72.4 & 76.5 & 91.5 & 11.8 & 13.5 & 4.89 & 74.6 & 12.6 & 0.025 & 0.729 & 0.005 \\
\hline $\begin{array}{l}\text { Extractable P } \\
\left(\mathrm{mg} \cdot \mathrm{kg}^{-1}\right)\end{array}$ & -1.48 & 1.78 & 0.12 & 721 & 864 & 749 & 132 & 253 & 275 & 739 & 164 & 0.138 & 0.075 & 0.905 \\
\hline
\end{tabular}

by the influence of climatic factors and vegetation on soil organic horizon fertility.

\section{Relationships between soil fertility and forest types}

Relationships between the vegetation pattern and the fertility of the soil organic horizon were identified at the regional level. The predominance of Cajander's site type 4 in NK is associated with a lower nutrient content and higher $\mathrm{C} / \mathrm{N}$ ratio in the organic horizons compared to those in $M K$, where the proportion of site type 3 is higher, and compared to those in MKI where the proportion of site types 2 and 3 is higher.

At the level of Cajander's site types, the relationships between vegetation formation and organic horizon fertility were also evident. In all three areas the nutrient content in the organic horizon increased from poor sites dominated by evergreen dwarf-shrubs and lichens to rich sites dominated by blueberry and herbs/grasses. The most informative soil parameters were $\mathrm{N}, \mathrm{C} / \mathrm{N}$ ratio, exchangeable $\mathrm{Ca}, \mathrm{Mg}, \mathrm{K}$, base saturation, which confirms the Finnish case study by Salemaa et al. (2008).

At the level of Sukachev's forest types the effects of predominant tree species were identified within Cajander's site types 2, 3, and 4. The organic horizons dominated by spruce and birch were more nutrient rich and less acidic compared to those dominated by pine.

The differences in the fertility of soil organic horizons could be explained by differences in the amount of precipitation penetrating through the canopy formed by different tree species. Augusto et al. (2015) found that the presence of evergreen Gymnosperm tree species generally induces a lower rate of precipitation input into the soil than the deciduous Angiosperm trees species, resulting in drier soil conditions and lower water discharge in the Gymnosperm communities. Christiansen et al. (2010) have shown that the mean annual percolation below the root zone of Norway spruce trees was significantly lower compared to that of deciduous trees.

The amount of precipitation below the crowns of Scots pine trees, especially the amount of water flowing down along the trunks, was considerably higher compared to that in Norway spruce forests of the northern taiga (Lukina et al. 2019). This effect can be explained by differences in the crown structure of different coniferous tree species. In the northern taiga, the crowns of old pine trees are open and short, whereas the crowns of old spruce trees are long and dense. Low amounts of precipitation penetrating through a dense and low canopy can prevent nutrient loss from the soil organic horizons in spruce forests. 


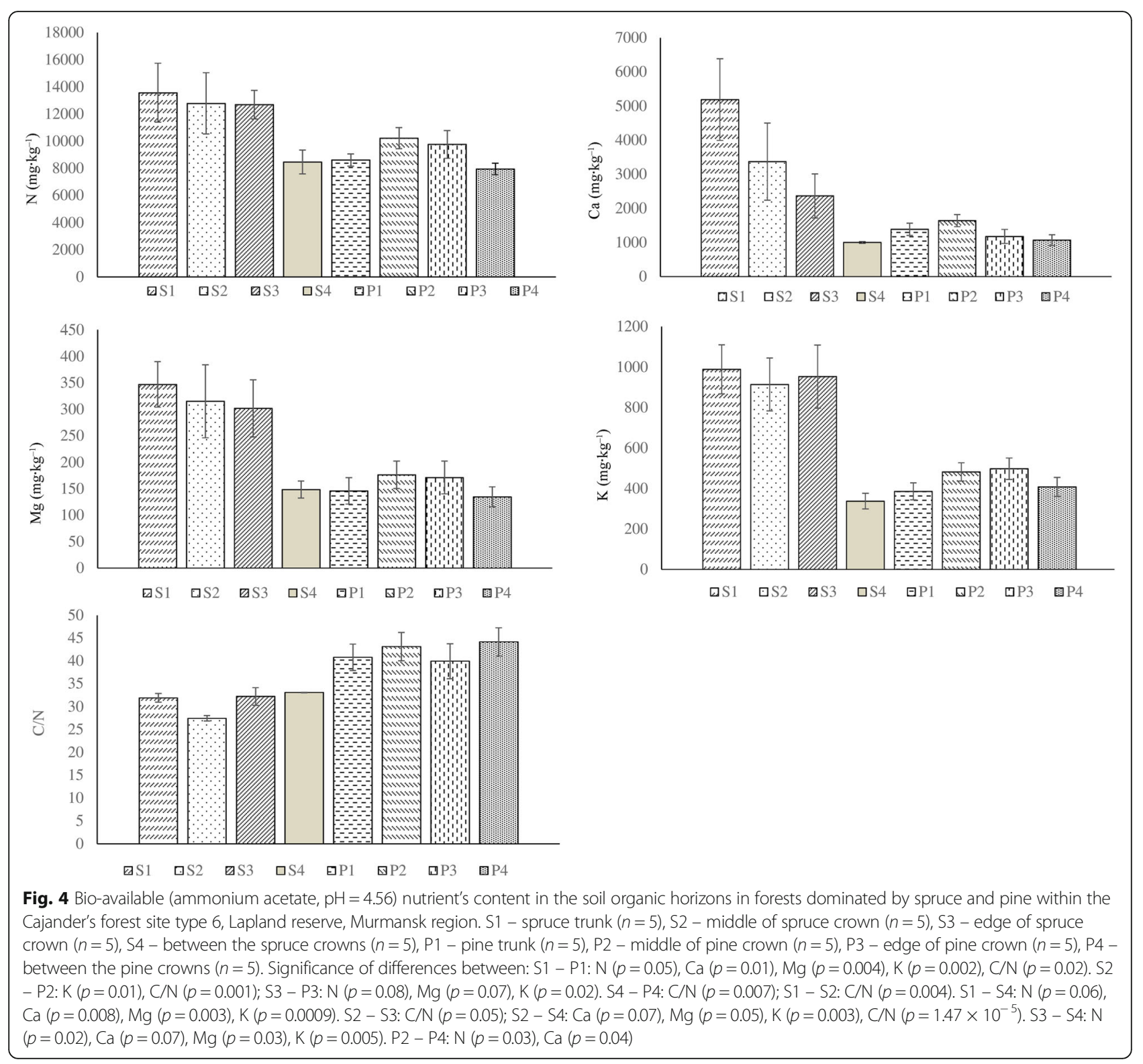

Higher nutrient contents in the organic horizons of spruce forests can also be explained by a high content of some nutrients in senescent spruce needles. An example is $\mathrm{Ca}$. Norway spruce is known to accumulate $\mathrm{Ca}$ in perennial needles. The Ca content in 12-13 year old needles of old spruce trees may reach $13-15 \mathrm{~g} \cdot \mathrm{kg}^{-1}$ in the northern taiga of the Murmansk region (Lukina and Nikonov 1998; Nikonov et al., 2004a, b). Ca is a non-mobile element, and it's concentration increases with needle age. Similar results were reported for manganese in forests at the northern tree line, an immobile element that is incapable of relocation within the trees (Lukina and Nikonov 1998; Nikonov et al., 2004a, b).

There were significant differences in the content of bioavailable nutrients in the organic horizons between the micro-zones in spruce forests within Cajander's site type 6 in the Lapland reserve of the Murmansk region (Fig. 4). The reason for the higher nutrient content could be the particular crown shape of spruce trees, and the high Ca content in senescent spruce needles, as explained before. The results were different in pine forests, as expected.

The higher nutrient content in the organic horizons in birch forests compared to those of pine and spruce forests can be explained by a high quality birch litter. In the humus layer of a replicated 35-year-old birch-spruce field experiment on Vaccinium myrtillus site type in middle-eastern Finland the $\mathrm{pH}$ was higher under birch than under spruce, and the $\mathrm{C} / \mathrm{N}$ ratio was lower under birch than under spruce (Smolander et al. 2005). 
Table 8 Correlation coefficients between climatic variables, tree stand characteristics, the fertility of soil organic horizons, and the number of plant species of different functional groups

\begin{tabular}{|c|c|c|c|c|c|c|c|c|c|c|}
\hline \multirow[t]{2}{*}{ Parameters } & Lichens & $\begin{array}{l}\text { Green } \\
\text { moss }\end{array}$ & $\begin{array}{l}\text { Grasses \& } \\
\text { sedges }\end{array}$ & $\begin{array}{l}\text { Dwarf } \\
\text { shrubs }\end{array}$ & Herbs & Lichens & $\begin{array}{l}\text { Green } \\
\text { moss }\end{array}$ & $\begin{array}{l}\text { Grasses \& } \\
\text { sedges }\end{array}$ & $\begin{array}{l}\text { Dwarf } \\
\text { shrubs }\end{array}$ & Herbs \\
\hline & \multicolumn{5}{|l|}{$R$} & \multicolumn{5}{|l|}{$p$} \\
\hline \multicolumn{11}{|l|}{ Climate } \\
\hline Sum of effective temperatures & -0.42 & 0.18 & 0.53 & -0.53 & 0.39 & 0 & 0.05 & 0 & 0 & 0 \\
\hline $\begin{array}{l}\text { Precipitation amount at the period of effective } \\
\text { temperatures }\end{array}$ & -0.38 & 0.03 & 0.41 & -0.45 & 0.26 & 0 & 0.73 & 0 & 0 & 0 \\
\hline Amount of precipitation per year & -0.37 & 0.10 & 0.37 & -0.45 & 0.23 & 0 & 0.30 & 0 & 0 & 0.01 \\
\hline Average annual temperature & -0.45 & 0.18 & 0.56 & -0.51 & 0.41 & 0 & 0.06 & 0 & 0 & 0 \\
\hline \multicolumn{11}{|l|}{ Forest inventory parameters (all areas) } \\
\hline Stand volume & -0.51 & 0.13 & 0.44 & -0.54 & 0.42 & 0 & 0.17 & 0 & 0 & 0 \\
\hline Height & -0.61 & 0.26 & 0.59 & -0.65 & 0.54 & 0 & 0 & 0 & 0 & 0 \\
\hline Diameter & -0.51 & 0.17 & 0.51 & -0.46 & 0.44 & 0 & 0.06 & 0 & 0 & 0 \\
\hline \multicolumn{11}{|l|}{ A0 Horizon } \\
\hline $\mathrm{pH} \mathrm{H} \mathrm{H}_{2} \mathrm{O}$ & -0.10 & 0.29 & 0.25 & -0.11 & 0.23 & 0.28 & 0 & 0.01 & 0.22 & 0.01 \\
\hline $\mathrm{pH} \mathrm{CaCl}{ }_{2}$ & -0.16 & 0.32 & 0.31 & -0.16 & 0.31 & 0.09 & 0 & 0 & 0.09 & 0 \\
\hline Total N & -0.34 & 0.18 & 0.40 & -0.36 & 0.35 & 0 & 0.05 & 0 & 0 & 0 \\
\hline $\mathrm{C} / \mathrm{N}$ & 0.24 & -0.22 & -0.33 & 0.31 & -0.32 & 0.01 & 0.02 & 0 & 0 & 0 \\
\hline Exchangeable $\mathrm{Ca}$ & -0.25 & 0.33 & 0.36 & -0.28 & 0.37 & 0.01 & 0 & 0 & 0 & 0 \\
\hline Exchangeable Mg & -0.12 & 0.33 & 0.27 & -0.14 & 0.30 & 0.18 & 0 & 0 & 0.12 & 0 \\
\hline Exchangeable K & -0.41 & -0.04 & 0.37 & -0.30 & 0.28 & 0 & 0.64 & 0 & 0 & 0 \\
\hline BS & -0.23 & 0.22 & 0.35 & -0.22 & 0.36 & 0.01 & 0.02 & 0 & 0.02 & 0 \\
\hline
\end{tabular}

The number and cover of plant species of certain functional types and the organic horizon fertility were interrelated. Close positive correlations were found between the herb and grass species density and total $\mathrm{N}$, exchangeable $\mathrm{Ca}, \mathrm{Mg}, \mathrm{K}$ in the organic horizons. In contrast, the correlations between the nutrient content and the density of dwarf shrub and lichen species were negative. Negative correlations were found between the density of herb and grass species and the $\mathrm{C} / \mathrm{N}$ ratios in the organic horizons. In contrast, the correlations between the $\mathrm{C} / \mathrm{N}$ ratios and the density of dwarf shrub and lichen species were positive.

These close correlations demonstrated that herbs and grasses can promote the development of upper soil horizons of higher fertility better than dwarf shrubs, lichens and mosses which can be explained by the chemical composition of the litter of different functional types. A high amount of phenolics in tissues of plants of the family Ericaceae decreases the $\mathrm{N}$ concentration, which impedes litter decomposition (Li et al. 2007). Black crowberry also contains large quantities of polyphenolic compounds (Wardle et al. 2003). Mosses are characterized by a low content of nutrients and water-soluble extractives (Hilli 2013), while lichens also have a very low nutrient content (Cornelissen 2007).
Thus, the litter quality, the chemical composition of the residues of the predominant plant species is of great importance for assessing and predicting the relationships between soil and plants. The crown structure of the predominant tree species, together with their litter quality, is affecting the intensity of nutrient leaching and nutrient accumulation in the soil.

\section{Conclusions}

Based on an extensive set of field observations, several key relationships between different forest site types/forest types, and the fertility of the organic soil horizons, were identified in three of taiga forest regions of northwestern Russia: the northern taiga and middle taiga of the Republic of Karelia, and the Karelian Isthmus. To assess these relationships, the influence of other important soil-forming factors was identified at the regional level, such as soil forming rock, the effect of the land use history and different climatic conditions. The content of exchangeable $\mathrm{Mg}$ and $\mathrm{K}$ in the organic horizons was related to the total content of these elements in the soil forming rock. The different results for $\mathrm{Ca}$ are explained by the specific land-use history in the Karelian Isthmus. Significant differences in the fertility of the soil organic horizons between the three regions are also explained by 
Table 9 Correlation coefficients between the climate, tree stand characteristics, the fertility of soil organic horizons and density of different plant functional groups

\begin{tabular}{|c|c|c|c|c|c|c|c|c|c|c|}
\hline \multirow[t]{2}{*}{ Parameters } & Lichens & $\begin{array}{l}\text { Green } \\
\text { moss }\end{array}$ & $\begin{array}{l}\text { Grasses \& } \\
\text { sedges }\end{array}$ & $\begin{array}{l}\text { Dwarf } \\
\text { shrubs }\end{array}$ & Herbs & Lichens & $\begin{array}{l}\text { Green } \\
\text { moss }\end{array}$ & $\begin{array}{l}\text { Grasses \& } \\
\text { sedges }\end{array}$ & $\begin{array}{l}\text { Dwarf } \\
\text { shrubs }\end{array}$ & Herbs \\
\hline & \multicolumn{5}{|l|}{$R$} & \multicolumn{5}{|l|}{$p$} \\
\hline \multicolumn{11}{|l|}{ Climatic characteristics } \\
\hline Sum of effective temperatures & -0.38 & -0.14 & 0.31 & -0.62 & 0.32 & 0 & 0.14 & 0 & 0 & 0 \\
\hline $\begin{array}{l}\text { Precipitation amount for the period of effective } \\
\text { temperatures }\end{array}$ & -0.35 & -0.12 & 0.25 & -0.54 & 0.24 & 0 & 0.19 & 0.01 & 0 & 0.01 \\
\hline Amount of precipitation per year & -0.35 & -0.13 & 0.25 & -0.53 & 0.24 & 0 & 0.16 & 0.01 & 0 & 0.01 \\
\hline Average annual temperature & -0.38 & -0.18 & 0.33 & -0.62 & 0.33 & 0 & 0.05 & 0 & 0 & 0 \\
\hline \multicolumn{11}{|l|}{ Forest inventory parameters } \\
\hline Stand volume & -0.33 & -0.16 & 0.27 & -0.42 & 0.41 & 0 & 0.08 & 0 & 0 & 0 \\
\hline Height & -0.45 & -0.21 & 0.31 & -0.48 & 0.47 & 0 & 0.03 & 0 & 0 & 0 \\
\hline Diameter & -0.34 & -0.09 & 0.28 & -0.31 & 0.36 & 0 & 0.32 & 0 & 0 & 0 \\
\hline \multicolumn{11}{|l|}{ A0 Horizon } \\
\hline $\mathrm{pH} \mathrm{H} \mathrm{H}_{2} \mathrm{O}$ & -0.04 & -0.22 & 0.24 & -0.22 & 0.18 & 0.66 & 0.02 & 0.01 & 0.02 & 0.06 \\
\hline $\mathrm{pH} \mathrm{CaCl}{ }_{2}$ & -0.07 & -0.28 & 0.27 & -0.24 & 0.24 & 0.46 & 0 & 0 & 0.01 & 0.01 \\
\hline Total N & -0.30 & -0.18 & 0.16 & -0.37 & 0.30 & 0 & 0.05 & 0.08 & 0 & 0 \\
\hline $\mathrm{C} / \mathrm{N}$ & 0.26 & 0.14 & -0.18 & 0.30 & -0.23 & 0 & 0.14 & 0.05 & 0 & 0.01 \\
\hline Exchangeable $\mathrm{Ca}$ & -0.20 & -0.22 & 0.21 & -0.34 & 0.24 & 0.03 & 0.02 & 0.02 & 0 & 0.01 \\
\hline Exchangeable Mg & -0.10 & -0.23 & 0.11 & -0.24 & 0.23 & 0.28 & 0.01 & 0.25 & 0.01 & 0.01 \\
\hline Exchangeable K & -0.30 & -0.29 & 0.26 & -0.30 & 0.20 & 0 & 0 & 0 & 0 & 0.03 \\
\hline BS & -0.18 & -0.25 & 0.30 & -0.28 & 0.24 & 0.05 & 0.01 & 0 & 0 & 0.01 \\
\hline
\end{tabular}

the vegetation patterns. The influence of the particular climatic conditions on the plant species composition can partly explain the differences in the organic horizon fertility between the three regions. As expected, the nutrient content in the organic horizons increased from poor to rich Cajander's forest site types. The most informative parameters were $\mathrm{N}, \mathrm{C} / \mathrm{N}$ ratio, exchangeable $\mathrm{Ca}, \mathrm{Mg}, \mathrm{K}$, and base saturation. The density of particular plant species communities and the fertility characteristics of the organic horizons were interrelated. Close positive correlations were found between the density of herbs and grasses and the nutrient content. For dwarf shrubs, lichens and mosses these correlations were negative. This result was explained by differences in the chemical composition of the litter of plants belonging to different functional groups. Significant differences in the fertility of the soil organic horizons were also found between Sukachev's forest types dominated by different tree species identified within Cajander's site types Oxalis-Myrtillus, Myrtillus, Vaccinium vitis-idaea, Cladonia. The organic horizons of the same Cajander site types dominated by birch and spruce contained significantly more nutrients, compared to those dominated by pine. The influence of tree species was due to litter quality and differences in the crown structure of tree species affecting nutrient leaching. This study identified close relationships between forest site types/forest types and the fertility of soil organic horizons in the taiga subzones of northwestern Russia.

Abbreviation

ICP Forests: International Co-operative Programme on Assessment and Monitoring of Air Pollution Effects on Forests

\section{Acknowledgements}

We thank Juha-Pekka Hotanen from Natural Resources Institute Finland (Luke) for helping us in identification of Cajander's site types in forests, located within the regular grid of plots in Karelia and the Karelian Isthmus.

\section{Authors' contributions}

NL, ET and MD: idea of paper, analysis of all materials and text writing; AK and TB: vegetation data collection and analysis; OB: soil data collection and analysis; VS: statistical data processing; MS: tree taxation data collection and analysis; SK: creation of Fig. 1; NZ: climatic data collection and analysis; AK, DT and AK: data base development; LI: data collection on soil from Murmansk region. All authors read and approved the final manuscript.

\section{Funding}

This study was supported by the Russian Science Foundation, project No. 16-17-10284, by Ministry of science and high education of Russian Federation, project No. AAAA-A18-118052400130-7, and was carried out under state order to the Karelian Research Centre of the Russian Academy of Sciences (Forest Research Institute).

\section{Availability of data and materials}

The datasets used and/or analyzed during the current study are available from the corresponding author on a reasonable request. 


\section{Ethics approval and consent to participate}

Not applicable.

\section{Consent for publication}

Not applicable.

\section{Competing interests}

The authors declare that they have no competing interests.

\section{Author details}

${ }^{1}$ Center for Forest Ecology and Productivity of the Russian Academy of Sciences, 117997 Profsoyuznaya st. 84/32, RU-117997, Moscow, Russia. ${ }^{2}$ Forest Research Institute, Karelian Research Centre of the Russian Academy of Science, Pushkinskaya st. 11, RU-185910, Petrozavodsk, Karelia, Russia. ${ }^{3}$ Institute of Physicochemical and Biological Problems of Soil Sciences of the Russian Academy of Science, Vitkevicha st.1, RU -142290, Pushchino, Moscow Region, Russia. ${ }^{4}$ Institute of Industrial Ecology Problems of the North, 184209 , Academichesky gorodok, 14a, Apatity, Murmansk Region, Russia.

\section{Received: 4 February 2019 Accepted: 14 June 2019}

Published online: 13 July 2019

\section{References}

Aleksandrova VD (1969) Plant Classification. Review of the principles of classification and classification systems in different geobotanical schools. Nauka, Leningrad (in Russian)

Augusto L, De Schrijver A, Vesterdal L, Smolander A, Prescott C, Ranger J (2015) Influences of evergreen gymnosperm and deciduous angiosperm tree species on the functioning of temperate and boreal forests. Biol Rev 90:444-66

Berg B (2000) Litter decomposition and organic matter turnover in northern forest soil. Forest Ecol Manag 133:13-22

Berkvist B, Folkeson $L$ (1995) The influence of tree species on acid deposition, proton budgets and element fluxes in south Sweden forest ecosystems. Ecol Bulletins 44:90-99

Binkley D, Giardina C (1998) Why do trees affect soils? The warp and woof of tree-soil interactions. Biogeochem 42:89-106

Binkley D, Sollins P, Bell R, Sachs D, Myrold D (1992) Biogeochemistry of adjacent conifer and alder/conifer ecosystems. Ecology 73:2022-2034

Budyko MI (1971) Climate and life. Gidrometeoizdat, Leningrad (in Russian)

Cajander AK (1909) Ueber Waldtypen. About forest types. Acta For Fenn 1(1):1-175

Cajander AK (1926) The theory of forest types. Acta For Fenn 29:108

Cajander AK (1949) Forest types and their significance. Acta For Fenn 56(4):1-71

Chertov OG (1981) Ecology of forest land (soil and ecological research of forest habitats). Nauka, Leningrad (in Russian)

Christiansen JR, Vesterdal L, Callesen I, Feberling B, Schmidt IK, Gundersen P (2010) Role of six European tree species and land - use legacy for nitrogen and water budgets in forests. Glob Change Biol 16(8):2224-2240. https://doi. org/10.1111/j1365-2486.2009.02076.x

Cornelissen JHC, van Bodegom PM, Aerts $\mathrm{R}$, Callaghan TV, van Logtestijn RSP, Alatalo J, Chapin FS, Gerdo R, Gudmundsson J, Gwynn-Jones D, Hartley AE Hik DS, Hofgaard A, Jonsdottir IS, Karlsson S, Klein JA, Laundre J, Magnusson B, Michelsen A, Molau U, Onipchenko VG, Quested HV, Sandvik SM, Schmidt IK, Shaver GR, Bjorn SB, Soudzilovskaia NA, Anna Stenstro F, Tolvanen F, Totland O, Wada N, Welker JM, Zhao X, Team MOL (2007) Global negative vegetation feedback to climate warming responses of leaf decomposition rates in cold biomes. Ecol Lett 10:619-627. https://doi.org/10.1111/j.14610248.2007.01051x

Doronina AY (2007) Vascular plants of the Karelian isthmus. Association of Scientific Publications, KMK (in Russian)

Ellenberg H, Weber HE, Düll R, Wirth V, Werner W, Paulissen D (1991) Zeigerwerte von Pflanzen in Mitteleuropa. Pointer values of plants in Central Europe. Scripta Geobot 18:1-248

Fedorchuk VN, Neshatayev VY, Kuznetsova ML (2005) Forest ecosystems of the northwest regions of Russia: Typology, dynamics, economic features. Hromis, St.-Petersburg (in Russian)

Frey TEA (1978) The Finnish school and forest site-types. In: Whittaker RH (ed) Classification of plant communities. The Hague, Boston, London, pp 81-110

Hilli S (2013) Significance of litter production of forest stands and ground vegetation in the formation of organic matter and storage of carbon in boreal coniferous forests. In: Merilä P, Jortikka S (eds) Forest condition monitoring in Finland - national report. The Finnish Forest Research Institute. http://www.metla.fi/metinfo/forest-condition/intensive-monitoring/foliarchemistry.htm. Accessed 04 Dec 2018

Hobbie SE (1992) Effects of plant species on nutrient cycling. Trends Ecol Evol 7: 336-339

Hotanen JP, Maltamo M, Reinikainen A (2008) Canopy stratification in Peatland Forests in Finland. Silva Fennica 40(1):53-76

Husson F, Le S, Pagès J (2017) Exploratory multivariate analysis by example using $\mathrm{R}$, 2nd edition. Chapman \& Hall/CRC

Isachenko GA (2004) The landscape of the Karelian isthmus and its imagery since 1944. Helsinki Fennia 182(1): 47-59. ISSN 0015-0010

Jones CG, Lawton JH, Shachak M (1994) Organisms as ecosystem engineers. Oikos 69:373-386

Karpachevsky LA, Dmitriev EA, Skvortsov EA, Bacevich VF (1978) Windfalls role in shaping the structure of the soil cover. The structure of the soil cover and the use of soil resources. Nauka, Moscow (in Russian)

Kryshen AM (2010) Types of forest vegetation conditions on automorphic soils in Karelia. Botani J 95(3):281-297 in Russian

Kuusipalo J (1983) Distribution of vegetation on mesic forest sites in relation to some characteristics of the tree stand and soil fertility. Silva Fenn 17: 403-418

Kuusipalo J (1985) An ecological study of upland forest site classification in southern Finland. Acta For Fenn 192:1-78

Le S, Josse J, Husson F (2008) FactoMineR: an R package for multivariate analysis. J Stat Softw 25(1):1-18

Li X, Han S, Zhang Y (2007) Indirect effects of precipitation variation on the decomposition process of Mongolian oak (Quercus mongolica) leaf litter. Front Forest China 2:417-423

Lovett G (1992) Atmospheric deposition and canopy interactions of nitrogen. In: Johnson D, Lindberg S (eds) Atmospheric deposition and forest nutrient cycling. Springer-Verlag, New York, pp 152-165

Lukina NV, Nikonov W (1998) Nutritious regime of forests of northern taiga: natural and technological aspects. KSC RAS, Apatity, Murmansk region. 316 p. [In Russian]

Lukina N, Orlova M, Bahmet O, Tikhonova E, Tebenkova D, Kazakova A, Kryshen A, Gornov A, Smirnov V, Shashkov M, Ershov V, Knyazeva S (2019) The vegetation impact on forest soil characteristics in Karelia Republic. Eurasian Soil Sci 5 in print

Muukkonen P. Takala T, Virtanen T (2009) Differences in the forest landscape structure along the Finnish-Russian border in southern Karelia. Scand J of Forest Res 24(2):140-148

Nikonov W, Lukina NV, Bezel VS, Belsky EA, Bespalov AY, Golovchenko AV, Gorbacheva T, Dobrovolskaya TG, Dobrovolsky W, Zukert NV, Isayeva LG, Lapenis AG, Maksimova IA, Marfenina OE, Panikova AN, Pinsky DL, Polyanskaya LM, Steinnes E, Utkin Al, Frontasyeva MV, Cybulski W, Chernov IY, Yatsenko-Chmielewskaya MA (2004a) Trace elements in the boreal forest. Nauka, Moscow (in Russian)

Nikonov W, Motuzova GV, Lukina NV, Dauvalter MV, Zorina AV (2004b) Influence of natural and technogenic factors on soils, soil and ground waters of Kola peninsula. Water Res 31(3):325-331

Orlova MA, Lukina NV, Artemkina NA, Smirnov VE (2016) The influence of spruce on acidity and nutrient content in soils of northern taiga dwarf shrub-green moss spruce forests. Eurasian Soil Sci 49(11):1276-1288

Polikarpov NP, Chebakova NM, Nazimova DI, Kuzmichev W (1986) Climate and mountain forests of Southern Siberia. Nauka, Novosibirsk (in Russian)

R Core Team (2018) R: a language and environment for statistical computing. $R$ Foundation for Statistical Computing, Vienna, Austria. https://www.R-project. org/. Accessed 04 Dec 2018

Rautiainen A, Virtanen T, Kauppi PE (2016) Land cover change on the isthmus of Karelia 1939-2005: agricultural abandonment and natural succession. Env Sci Pol 55:127-134

Salemaa M, Derome J, Nojd P (2008) Response of boreal forest vegetation to the fertility status of the organic layer along a climatic gradient. Boreal Env Res 13:48-66

Smolander A, Loponen J, Suominen K, Kitunen V (2005) Organic matter characteristics and $\mathrm{C}$ and $\mathrm{N}$ transformations in the humus layer under two tree species, Betula pendulaand Picea abies. Soil Biol Biochem 37:1309-1318

Sukachev VN (1972) Concepts forest biogeocoenology. Selected works. Science, Leningrad 1:311-356 (in Russian)

Tonteri T, Mikkola K, Lahti T (1990) Compositional gradients in the forest vegetation of Finland. J Veget Sci 1(5):691-698

USSR Climate Reference Book (1965) Air temperature. Soil 3(2):144 (in Russian) 
USSR Climate Reference Book (1965-1968) Precipitation, snow cover. Soil 3(4):173 (in Russian)

Van Breemen N, Finzi AC (1998) Plant-soil interactions: ecological aspects and evolutionary implications. Biogeochem 42:1-19

Volkov AD (2008) Karelian forest types. Petrozavodsk: Karelian research Centre of RAS (in Russian)

Wardle DA, Nilsson MC, Zackrisson O, Gallet C (2003) Determinants of litter mixing effects in a Swedish boreal forest. Soil Biol Biochem 35:827-835

Zukert NV (2000) Possible shifts of borders of vegetable zones in Yakutia at climate change. Probl Region Ecol 4:74-81 in Russian

Zukert NV (2006) Climatic map and distribution of vegetation zones of Russia. Lesovedenie 1:14-12 in Russian

Zukert NV (2008) Monitoring of biodiversity of the woods of Russia. In: Isaev AS (ed) Zoning the territory of the Russian Federation on the basis of meteorological parameters. Nauka (in Russian)

\section{Submit your manuscript to a SpringerOpen ${ }^{\circ}$ journal and benefit from:}

- Convenient online submission

- Rigorous peer review

- Open access: articles freely available online

- High visibility within the field

- Retaining the copyright to your article

Submit your next manuscript at $\boldsymbol{\nabla}$ springeropen.com 